
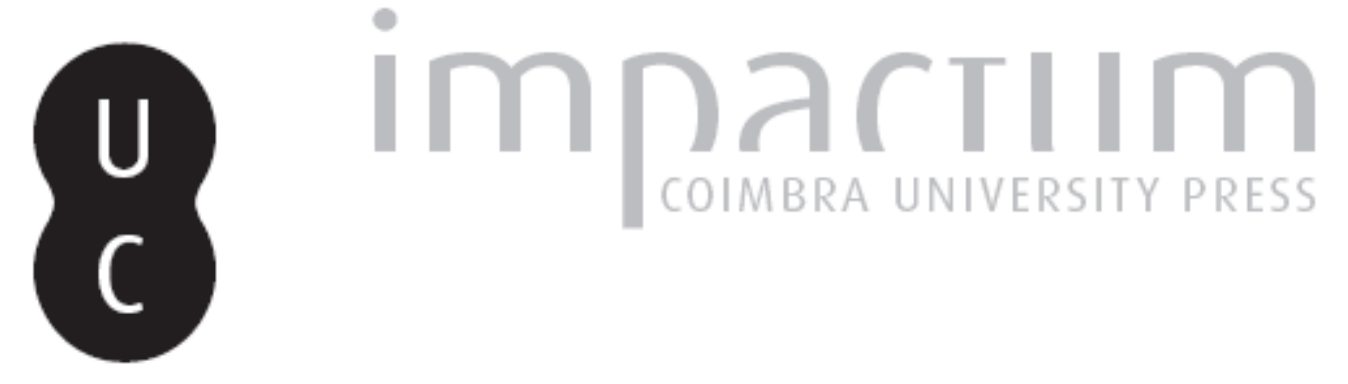

\title{
Bioterrorismo: sinopse evolutiva e intervenção sanitária atual
}

Autor(es): $\quad$ Braga, Gisélia; Leão, Rui Ponce; Bandeira, Romero

Publicado por: Associação Portuguesa de Riscos, Prevenção e Segurança; Imprensa da Universidade de Coimbra

URL persistente:

URI:http://hdl.handle.net/10316.2/39731

DOI:

DOI:https://doi.org/10.14195/1647-7723_23_7

Accessed : $\quad$ 26-Apr-2023 15:17:39

A navegação consulta e descarregamento dos títulos inseridos nas Bibliotecas Digitais UC Digitalis, UC Pombalina e UC Impactum, pressupõem a aceitação plena e sem reservas dos Termos e Condições de Uso destas Bibliotecas Digitais, disponíveis em https://digitalis.uc.pt/pt-pt/termos.

Conforme exposto nos referidos Termos e Condições de Uso, o descarregamento de títulos de acesso restrito requer uma licença válida de autorização devendo o utilizador aceder ao(s) documento(s) a partir de um endereço de IP da instituição detentora da supramencionada licença.

Ao utilizador é apenas permitido o descarregamento para uso pessoal, pelo que o emprego do(s) título(s) descarregado(s) para outro fim, designadamente comercial, carece de autorização do respetivo autor ou editor da obra.

Na medida em que todas as obras da UC Digitalis se encontram protegidas pelo Código do Direito de Autor e Direitos Conexos e demais legislação aplicável, toda a cópia, parcial ou total, deste documento, nos casos em que é legalmente admitida, deverá conter ou fazer-se acompanhar por este aviso.

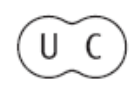




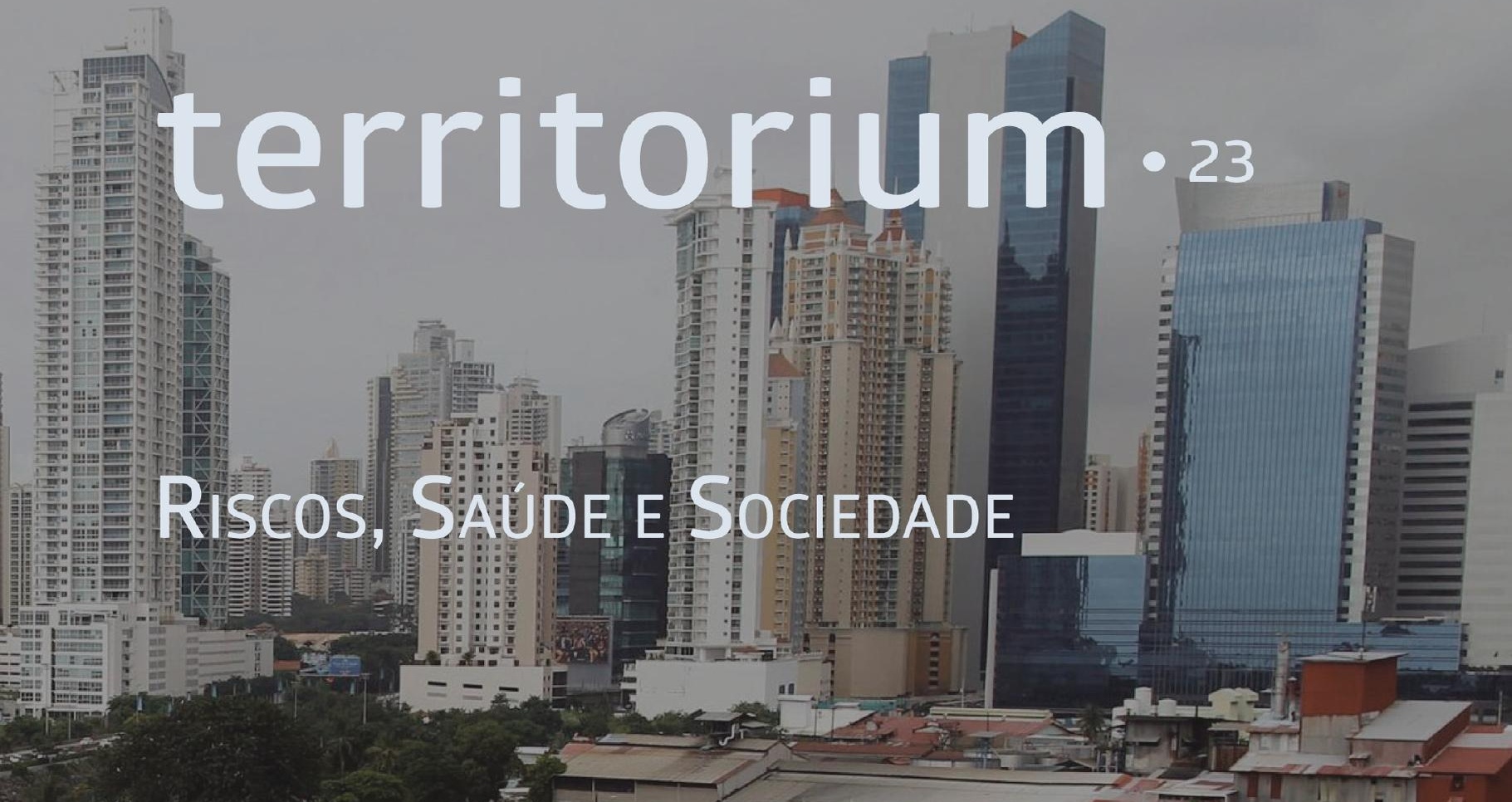

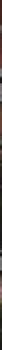

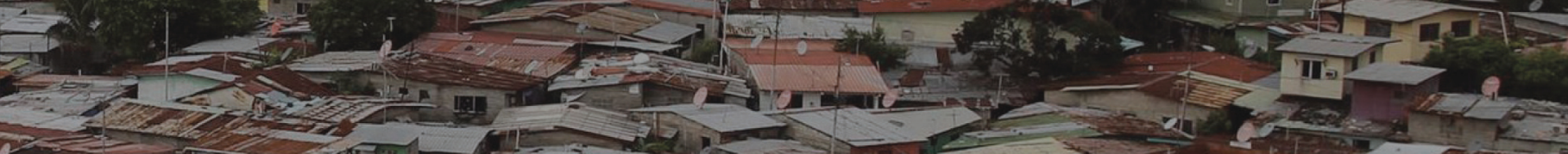

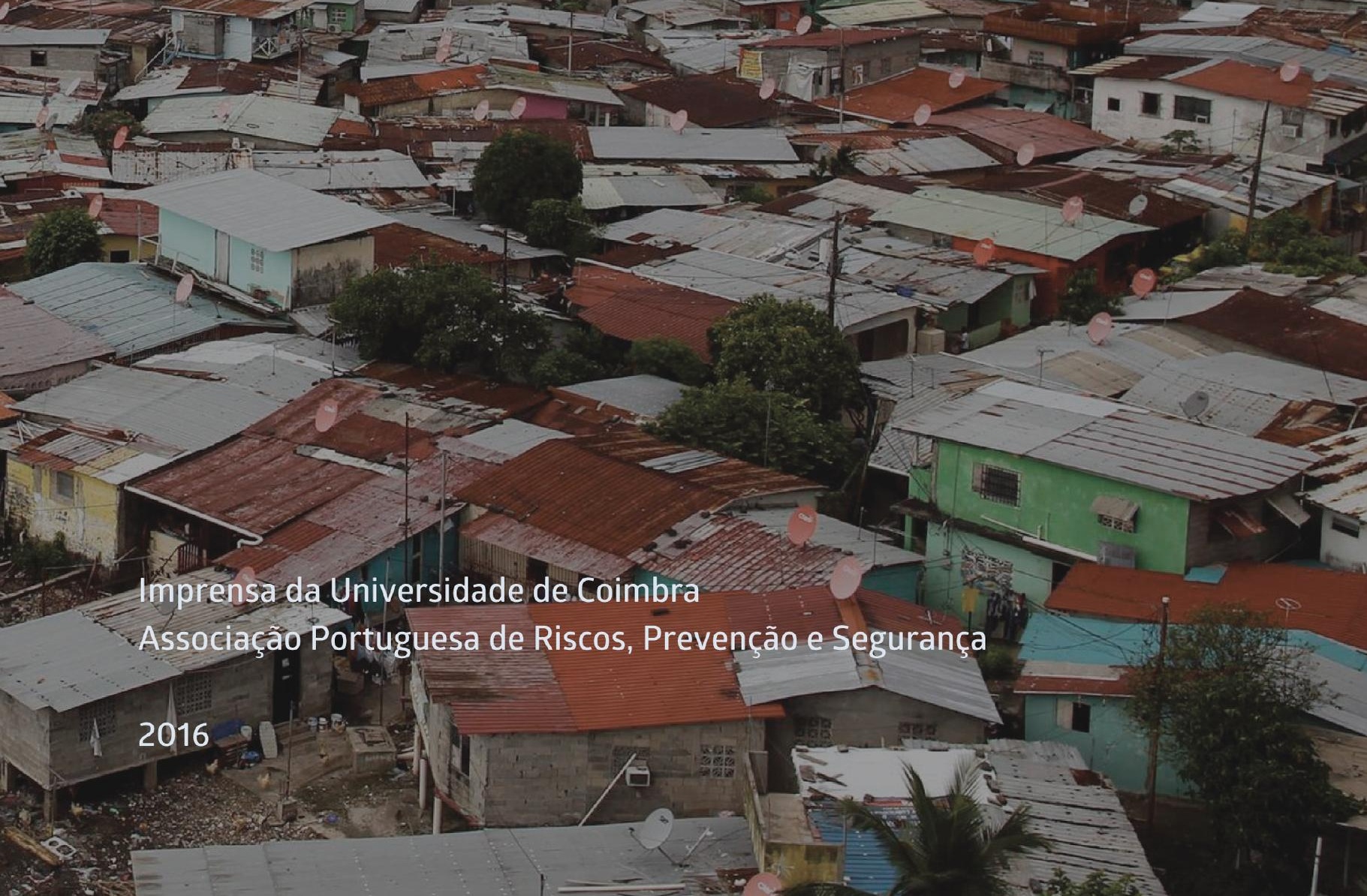




\title{
BIOTERRORISMO: SINOPSE EVOLUTIVA E INTERVENÇÃO SANITÁRIA ATUAL*
}

\author{
BIOTERRORISM: EVOLUTION SYNOPSIS AND CURRENT SANITARY INTERVENTION
}

Gisélia Braga

Unidade de Prevenção e Controlo de Infeção e Resistência aos Antimicrobianos (UPCIRA), CH S. João Consultora da UEIFIS-AHCBV SP Cova giseliabraga@gmail.com

Rui Ponce Leão

Hospital de Santa Maria do Porto Consultor da UEIFIS-AHCBV SP Cova ruipleao@gmail.com

Romero Bandeira

ICBAS-UM. Porto

Diretor da UEIFIS-AHCBV SP Cova hmedcat@icbas.up.pt

\section{RESUMO}

Após os ataques terroristas em 2011 aos Estados Unidos da América (EUA) e embora não tenha sido identificado nenhum na Europa, os países sofreram uma forte pressão de forma a estabelecerem planos para enfrentar este novo tipo de ameaça. Os hospitais vão ser uma referência para quem começa a sentir-se doente, portanto terão que estar preparados. Tornase necessário tomar medidas para minimizar as consequências e será necessário ter um plano de contingência para uma situação de Bioterrorismo, evitando ou, no mínimo, reduzindo a mortalidade e morbilidade das vítimas.

Palavras-chave: Armas biológicas, doença, hospital, morte.

\section{ABSTRACT}

Even though no terrorist attack was identified in Europe, after the 2001 terrorist attacks in the USA, these countries suffered a big pressure to establish plans for this type of threat. Hospitals will be a reference for those who feel ill, so they will have to be prepared. Thus it is necessary to take measures to reduce the consequences, a contingency plan will be necessary for a bioterrorism situation preventing or at least reducing victim's mortality and morbidity.

Keywords: Biological weapons, disease, hospital, death.

\section{RESUMEN}

Bioterrorismo: sinopsis de la evolución y intervención sanitaria actual - Después de los ataques terroristas de 2011 en los Estados Unidos de América (EUA), y a pesar de no haber sido identificado ninguno en Europa, los países han sufrido una gran presión para establecer planos para enfrentar este nuevo tipo de amenaza. Los hospitales van a ser una referencia para quien empieza a sentirse enfermo, por lo que tendrán que estar preparados. Se hace necesario tomar medidas para minimizar las consecuencias y será necesario tener un plan de contingencia para una situación de Bioterrorismo, evitando o, al menos, reduciendo la mortalidad y morbilidad de las víctimas.

Palabras clave: Armas biológicas, enfermedad, hospital, muerte.

\section{RESUMÉ}

Bioterrorisme: synopsis et intervention sanitaire actuelle - Après les attentats terroristes aux États Unis de 2011, bien qu'il n'y en ait eu aucun en Europe, les pays ont ressenti une très forte pression qui les a amenés à mettre en place des plans pour faire face à ce type de menace. En cas d'attentats bioterroristes, les hôpitaux qui doivent accueillir les victimes devront être prêts. Il s'avère donc nécessaire de prendre des mesures pour limiter les conséquences et de prévoir un plan d'action, pour éviter ou diminuer la mortalité et la morbidité des victimes.

Mots-clé: Armes biologiques, maladie, hôpital, mort.

* O texto deste artigo corresponde a uma comunicação apresentada no III Congresso Internacional, I Simpósio Ibero-Americano e VIII Encontro Nacional de Riscos, tendo sido submetido em 04-02-2015, sujeito a revisão por pares a 18-06-2015 e aceite para publicação em 31-03-2016.

Este artigo é parte integrante da Revista Territorium, n. ${ }^{\circ} 23,2016,{ }^{\circ}$ RIscos, ISSN: 0872-8941. 
Introdução

Após os ataques terroristas de 11 de Setembro de 2001, os EUA sofreram uma vaga de incidentes bioterroristas associados a esporos de Bacillus anthracis. Estes atos tiveram repercussões notáveis na Europa. Embora não tenha sido identificado nenhum ataque bioterrorista dirigido à Europa, os países sofreram uma forte pressão, na medida em que tiveram rapidamente de encontrar meios para enfrentar este novo tipo de ameaça (Pires e Silva, 2009).

Portugal não ficou indiferente a esta situação e, em 2002, publicou a Lei de Combate ao Terrorismo (em cumprimento da Decisão Quadro no 2002/475/JAl, do Conselho, de 13 de Junho), atualizada em 2003 pela Lei $n^{\circ}$ 52/2003 de 22 de Agosto. Salvaguardando os casos de Bioterrorismo, refere "Crimes que impliquem o emprego de energia nuclear, armas de fogo, biológicas ou químicas, substâncias ou engenhos explosivos, meios incendiários de qualquer natureza, encomendas ou cartas armadilhadas sempre que, pela sua natureza ou pelo contexto em que são cometidos, estes crimes sejam suscetíveis de afetar gravemente o Estado ou a população que se visa intimidar".

O Bioterrorismo tem claras implicações na Saúde Pública pelo impacto resultante da libertação intencional de agentes biológicos com capacidade de replicação e facilmente propagáveis ou transmissíveis. Neste contexto, em eventuais situações de ataques e ameaças bioterroristas, os profissionais de saúde estarão na "linha da frente" como primeiro elemento do contacto com o problema (Circular Normativa (CN) n¹2/DT de 0209-2002).

Será necessário tomar medidas para diminuir esse impacto e causar as menores alterações possíveis tanto a nível de profissionais de saúde como no funcionamento das instituições e mesmo do país. Assim, no Despacho n¹8923/2002 de 26 de Agosto, o Ministério da Saúde alerta para a necessidade de elaborar um plano de contingência com a finalidade de minimizar as consequências de eventuais ataques.

Em continuidade, a Direção Geral da Saúde (DGS) publicou a CN n¹2/DT de 02 de Setembro de 2002, onde aprova o Plano "Bioterrorismo - Plano de Contingência Português para a Saúde", devido à necessidade de serem criadas condições para responder, de forma rápida e coordenada, caso ocorra uma ameaça ou ato de Bioterrorismo.

Face ao acima exposto e perante a importância do tema tratado, dado o impacto social do Bioterrorismo, achou-se pertinente, com base na Tese de Mestrado, intitulada "BIOTERRORISMO: Proposta de um Plano de Contingência Hospitalar a Implementar Face a uma Ameaça", defendida no Instituto Ciências Biomédicas Abel Salazar (ICBAS), em Novembro de 2010, no âmbito do Mestrado de Medicina de Catástrofe, elaborar este texto, com o objetivo de sensibilizar para este risco e atualizar o tema.

Para a recolha de informação, procedeu-se à pesquisa bibliográfica, nomeadamente nas bibliotecas da Universidade do Porto, diversos sites de Internet, legislação portuguesa e outras fontes, com especial atenção aos sites oficiais de organizações internacionais e nacionais, como por exemplo a Organização Mundial de Saúde (OMS), Centers for Disease Control and Prevention (CDC) e DGS.

\section{Catástrofe / Bioterrorismo}

O conceito de catástrofe muito para além da sua definição baseia-se em três componentes:

- Afluxo intenso de vítimas;

- Destruição de ordem material;

- Desproporcionalidade acentuada entre os meios humanos e materiais de socorro e as vítimas a socorrer (Bandeira, 2008).

Segundo a OMS, "catástrofe é qualquer acontecimento que cause estragos, desestabilização económica, perda de vidas humanas e deterioração da saúde e dos serviços de saúde, a uma escala tal, que justifique uma mobilização excecional de auxílios vindos de fora da comunidade ou da zona atingida" (Bandeira, 2008).

Segundo o CDC (2009a), Bioterrorismo é a libertação deliberada de vírus, bactérias ou outros microrganismos (agentes), utilizados para causar doença ou morte em pessoas, animais e plantas.

A Comissão Europeia define Bioterrorismo como a ameaça de ataques deliberados com agentes biológicos (Saúde-UE, 2009).

Este tipo de evento pode ser considerado um acidente grave ou mesmo uma catástrofe, visto que provoca instabilidade económica, perda de vidas humanas e deterioração de saúde e dos serviços de saúde, que poderá justificar a mobilização excecional de auxílios vindos de fora da comunidade ou da zona atingida, como foi referido anteriormente na definição da OMS.

Segundo a classificação acima referida em Bandeira (2008), o Bioterrorismo pode ser classificado como uma Catástrofe Conflitual e Sociológica - Conflitos Armados Internacionais: Armas Bacteriológicas.

\section{Sinopse Histórica do Bioterrorismo}

A história da guerra biológica é quase tão antiga como a própria história da guerra e está repleta de episódios que são exemplo da utilização de organismos vivos ou 
dos seus produtos para combater o inimigo, como por exemplo o uso de flechas com toxinas naturais (Pires e Silva, 2009).

$\mathrm{O}$ incidente mais antigo documentado do uso de armas biológicas é entre 1500-1200 AC, em que as vítimas de peste foram levadas para as terras dos inimigos. Outra situação descrita por estas autoras, é a contaminação de poços com centeio atacado de cravagem provocando ergotismo quando alguém o ingeria, facto que nunca foi provado.

De acordo com poemas de Homero, foram utilizadas lanças e flechas envenenadas para destruir o inimigo. Durante a primeira Guerra Sagrada, na Grécia, por volta de $590 \mathrm{AC}$, houve contaminação do abastecimento de água e dos poços da cidade (Pires e Silva, 2009).

Durante o séc. IV, arqueiros contaminavam as suas flechas com veneno de cobra, sangue e fezes de animais com intuito de contaminar as feridas das suas vítimas.

Na Idade Média, as vítimas de peste bubónica eram usadas para ataques biológicos: para o efeito eram arremessados cadáveres e fezes sobre as muralhas dos castelos inimigos, usando catapultas (Sanches-Yáñez e Menjivar, 2008).

Em 1340, durante a Guerra dos 100 anos, também está descrito que os atacantes lançaram animais em decomposição na área do inimigo. Em 1346, corpos dos guerreiros mongóis que tinham morrido de peste, foram lançados sobre os muros de Kaffa. Especula-se que esta operação pode ter sido a responsável pela peste negra na Europa. Durante várias guerras que foram surgindo continuaram a usar este método para atacar o povo inimigo (Mandell et al., 2005).

De acordo com Sanches-Yáñez e Menjivar (2008), no séc. XVIII, durante a guerra franco-indígena (1754-1767), Sir Jeffrey Amherst, comandante britânico na América do Norte, sugeriu o uso deliberado da varíola para reduzir as tribos americanas. Em 24 de Junho de 1763, o capitão Ecuyer, um dos subordinados de Amherst, deu cobertores contaminados com o vírus da varíola aos nativos americanos. Tal ação foi seguida por uma epidemia de varíola entre as tribos indígenas, apesar do contacto entre colonos e nativos poder também ter contribuído para esta epidemia.

Entre 1914 e 1918, a Alemanha desenvolveu um ambicioso programa de guerra biológica durante a I Guerra Mundial, incluindo operações secretas no comércio dos Países Neutros com os Aliados (com o intuito de infetar armazenamentos de alimentos e contaminar animais a serem exportados para as forças inimigas). Os agentes do carbúnculo e mormo foram usados para infetar ovelhas vindas da Roménia e que iam ser exportadas para a Rússia, citando os mesmos autores.
Em 1925, foi realizado o primeiro esforço diplomático com o objetivo de limitar a guerra biológica, através do Protocolo de Proibição do Uso de Gases Asfixiantes, Venenosos ou Outros e Métodos Bacteriológicos de Guerra durante os Conflitos, em Genebra. Os signatários do Protocolo de Genebra, começaram programas básicos de pesquisa e desenvolvimento de armas biológicas depois da I Guerra, incluindo Bélgica, Canadá, França, GrãBretanha, Itália, Holanda, Polónia, e União Soviética. Os EUA não validaram o protocolo de Genebra até 1975 (Pires e Silva, 2009).

Entre 1940 e 1944 o Japão conduziu pesquisas e desenvolveu armas biológicas, e, na campanha contra a Coreia e a Manchúria, bombardearam onze cidades chinesas com bombas que continham material contaminado com Peste e Tifo. O número de mortes na população civil nunca foi avaliado. Os japoneses testaram diversas doenças em 3000 prisioneiros de guerra que se encontravam nos campos de concentração, 1000 desses prisioneiros faleceram devido a essas experiências. Entre esses prisioneiros encontravam-se pessoas de diferentes nacionalidades, entre as quais: americanas, britânicas, chinesas, coreanas e mongólicas.

Destas estratégias surgiram diversas formas de transmissão e transporte de doenças infeciosas, desde determinado local até outros lugares mais longínquos, como por exemplo através de balões de hidrogénio que podiam atingir 11000 metros de altura para alcançar a corrente de ar continental e em 86 horas chegavam à costa dos EUA; estas bolas continham pérolas de cerâmica com pulgas infetadas com Yersinia pestis, mas algo não correu como esperavam e estes globos foram destruídos durante a viagem, referem Sanches-Yáñez e Menjivar (2008).

Segundo Tavolaro (2004), os EUA pulverizaram culturas com agentes biológicos através de aviões e também libertaram, pelo menos, 12 milhões de pulgas para provocar epidemia de peste. No ataque a Changteickn, em 1941, houve aproximadamente 10000 vítimas e 1700 mortes entre as tropas japonesas. Frequentemente, ocorriam acidentes e os ensaios de campo foram terminados em 1942, apesar da pesquisa básica continuar até o final da guerra.

Em Dezembro de 1941 foi solicitado a Winston Churchill autorização para produzir a primeira arma biológica (Pires e Silva, 2009).

No período entre 1939-1945, Hitler emitiu ordens expressas proibindo o desenvolvimento de armas biológicas na Alemanha. Porém, com suporte de altos oficiais nazis, cientistas alemães iniciaram programas de produção de armas biológicas, apesar dos resultados se manterem aquém dos outros países. Prisioneiros em campos de concentração nazis foram infetados com Rickettsia prowazekii, Rickettsia mooseri, vírus da 
hepatite A, Plasmodium spp e tratados com vacinas e drogas para teste. Tais estudos eram utilizados para compreender as doenças, para desenvolver vacinas e antibióticos mais eficientes, ao contrário de criar armas biológicas. 0 único acontecimento conhecido de guerra biológica utilizado pelos alemães foi a contaminação de um grande reservatório no nordeste da Boémia, com fezes, em Maio de 1945 (UNIFEST, 2009).

Por volta de 1942, os EUA iniciaram um programa biológico sob a direção de uma Agência Civil. O programa incluía uma unidade de pesquisa e desenvolvimento em Forte Detrick, uma de teste no Mississipi e outra unidade de produção em Indiana (UNIFEST, 2009). Durante a II Guerra Mundial implementaram uma produção em larga escala quando aproximadamente 5000 bombas de esporos de carbúnculo foram produzidas naquele complexo, mais concretamente na Unidade 731. Vários cientistas japoneses, sob custódia americana e que haviam participado nessa Unidade, ganharam imunidade sob condição de revelar informações obtidas durante o seu programa, como descreve em UNIFEST (2009).

Entre 1947 e 1990 numerosas acusações não fundamentadas de uso de armas biológicas foram feitas durante a Guerra Fria, incluindo acusações soviéticas de testes americanos com esquimós canadianos, resultando numa epidemia de peste. Os EUA também foram acusados de iniciar uma epidemia de cólera no Sudeste da China e de Dengue em Cuba. Igualmente, as forças armadas soviéticas e suas aliadas foram acusadas pelos EUA de uso de armas biológicas no Laos e no Afeganistão.

Nos anos de 1950 e 1960, o governo americano instalou no estado de Maryland o complexo de laboratórios militares em Forte Detrick. Na fase mais ativa, chegaram a trabalhar cerca de mil cientistas dedicados à investigação de armas biológicas. Várias experiências foram conduzidas usando agentes patogénicos, incluindo Bacillus anthracis e Brucella suis.

Os aliados desenvolveram armas biológicas para uma retaliação em resposta a um potencial ataque biológico alemão, refere Pires e Silva (2009).

Em 1951 foi criado, nos Estados Unidos, o programa de armas biológicas, vindo a ser oficialmente encerrado em 1969, pelo presidente Nixon, de acordo com Van Aken (2003) citado pelas mesmas autoras.

A União Soviética, a China e a Coreia do Norte acusaram os EUA de usar armas biológicas durante a Guerra da Coreia. Os EUA admitiram possuir capacidade de Guerra Biológica, mas negaram o seu uso na região. A credibilidade americana era baixa devido à não validação do protocolo de Genebra de 1925, além da suspeita colaboração secreta dos cientistas da Unidade 731 (UNIFEST, 2009).
No final dos anos 60 os militares americanos desenvolvem um arsenal biológico que inclui numerosos agentes patogénicos, toxinas e fungos que podiam ser utilizados contra colheitas para induzir quedas na produção e fome, como descreve UNIFEST (2009). Além disso, armas para uso secreto, como venenos de cobra e outras toxinas foram desenvolvidas pela Central Intelligence Agency $(\mathrm{CIA})$, sendo que todos os registos sobre o seu desenvolvimento e uso, foram destruídos.

Em Julho de 1969, a Grã-Bretanha propõe ao Comité de Desarmamento da Organização das Nações Unidas (ONU) a proibição do desenvolvimento, produção e armazenamento de armas biológicas, prevendo inspeções em resposta a alegações de violações ao tratado (UNIFEST, 2009).

Entre Maio de 1971 e Fevereiro de 1973 houve destruição do armazenamento americano, sob orientação do Departamento da Agricultura, Departamento da Saúde, Educação e Bem-estar e Departamento dos Recursos Naturais. Grande parte da informação sobre o programa também foi destruída, menciona UNIFEST (2009).

Em Abril de 1972 é realizada a validação do Tratado de Proibição do Desenvolvimento, Produção, Armazenamento de Armas Biológicas e de Toxinas. O Tratado proibia o desenvolvimento, armazenamento de agentes biológicos ou toxinas em "quantidades não justificadas para fins profiláticos, de proteção ou pacíficos”. Porém, existem controvérsias sobre quais seriam essas quantidades e do que realmente entendiam por "pesquisa defensiva", além do tratado não incluir mecanismos de verificação de cumprimento pelos Estados participantes.

Em 1979, os serviços de inteligência do bloco soviético assassinam o dissidente búlgaro radicado em Londres, Geogi Markov, com uso de rícino (UNIFEST, 2009).

Surge uma epidemia de carbúnculo na cidade de Sverdlovsk (atual Ekaterinburg, Rússia), nas proximidades de uma instalação militar secreta.

Em Março de 1995 a Polícia Japonesa descobre na sede da Seita Aum Shinrikyo evidências de produção rudimentar de armas biológicas (UNIFEST, 2009).

A Comissão Especial da ONU no Iraque (UNSCOM) em 1996 destrói as instalações de pesquisa e produção de armas biológicas iraquianas, referem Pires e Silva (2009).

Porém, a história da ameaça biológica estava longe de ter terminado. Semanas depois do ataque de 11 de Setembro de 2001, foram enviadas cartas contendo bacilos do carbúnculo, nos EUA, infetando algumas pessoas e criando pânico generalizado. Apesar da mortalidade ser reduzida (7 mortos), os impactos social e económico foram muito elevados como mencionam Pires e Silva (2009). 
Referem ainda que as investigações sugerem que as libertações deliberadas provinham de uma única fonte e as estirpes detetadas de carbúnculo não eram distinguíveis. Os autores destes atos não foram identificados e o risco de novas libertações deliberadas permanece elevado, enquanto se desconhece a fonte.

Os atos terroristas ocorreram nos EUA, mas tiveram um impacto mundial. Na Europa, os serviços de proteção civil, de segurança e as forças armadas foram colocados de prevenção e os sistemas de Saúde Pública tiveram de gerir numerosos envios postais que continham pós, alegadamente suspeitos de contaminação com Carbúnculo. Não se registaram ataques terroristas com carbúnculo nem contaminações na Europa, se excluirmos uma carta contaminada detetada na Embaixada dos EUA, em Viena de Áustria. Foi, porém, grande a pressão exercida sobre os países europeus, visto que tiveram de consagrar rapidamente os escassos recursos de Saúde Pública no combate a um novo tipo de ameaça (EUR-Lex, 2010).

Em Portugal, mais concretamente no Porto, e segundo pesquisa realizada no registo de ocorrências, gentilmente facultado, do Batalhão de Sapadores Bombeiros desta cidade, desde Setembro de 2001 até Dezembro desse mesmo ano, foram registadas 31 ocorrências por suspeita de contaminação por carbúnculo. 0 mês de Outubro foi o que contou com mais ocorrências (18 situações), nas quais foi detetado "Pó branco" na correspondência de uma residência, numa outra correspondência vinda de Inglaterra e entregue numa residência, e também aparecimento de "Pó branco" em escolas, entre outras.

Em 7 de Janeiro de 2003, na sequência de uma rusga efetuada dois dias antes em Londres, as autoridades britânicas anunciaram que os testes realizados a uma pequena quantidade de material encontrado num edifício tinham dado resultados positivos quanto à presença de rícino. 0 incidente veio recordar, às autoridades responsáveis pela segurança e pela saúde, a necessidade de intensificarem os seus esforços para planear e estarem prontas para uma propagação deliberada de agentes biológicos e químicos (Pires e Silva, 2009).

Contudo, em todos os casos referidos, os agentes foram utilizados na forma em que surgem na natureza, com as limitações próprias do seu estado natural. Foi com o aparecimento da engenharia genética, no século XX, e o consequente desenvolvimento de novas ferramentas para analisar e modificar especificamente o material genético de um organismo, que se deu um aumento do risco de guerra biológica alertam Pires e Silva (2009).

\section{Agentes Biológicos Como Armas}

No Bioterrorismo podem ser usados como armas, microrganismos ou toxinas de origem biológica, utilizados para infetar pessoas, animais ou plantas. Para um agente biológico ser usado como arma não basta ser muito tóxico e infecioso, mas tem de reunir diversas características essenciais. Os agentes biológicos têm a capacidade de prejudicar a saúde humana sob diversas formas, desde leves reações alérgicas até situações médicas graves, que podem levar à morte. Estes organismos são ubíquos no ambiente natural, sendo encontrados na água, solo, plantas e animais (CDC, 2009a).

O CDC (2009b) classificou os agentes biológicos passíveis de serem utilizados como armas biológicas em 3 categorias (A, B e C), de acordo com os seguintes parâmetros:

- Elevada mortalidade/morbilidade;

- Infecciosidade;

- Eficácia em baixas doses;

- Múltiplas possibilidades de transmissão (aerossol, água, alimentos, insetos);

- Fáceis de se encontrar e reproduzir;

- Fácil disseminação;

- Grau de patogenicidade;

- Estabilidade durante a produção, armazenamento, transporte e disseminação;

- Menos dispendioso que outras armas de destruição em massa;

- Difíceis de detetar, não têm cheiro nem cor;

- Período de incubação curto;

- $\quad$ Ausência de tratamento;

- Sem imunização.

\section{Classificação dos Agentes Biológicos}

$\mathrm{Na}$ Categoria A estão incluídos os agentes de prioridade máxima. Incluem aqueles que colocam em risco a segurança, que podem ser facilmente disseminados ou transmitidos pessoa a pessoa e causam elevada taxa de mortalidade. Tem ainda um elevado potencial para provocar impacto na Saúde Pública, causando pânico na população e rotura social e requerem ações especiais de preparação e resposta por parte dos Sistemas de Saúde Pública.

$\mathrm{Na}$ Categoria B estão englobados os agentes de segunda maior prioridade, que incluem aqueles que são moderadamente fáceis de disseminar, causam morbilidade moderada e baixa mortalidade, implicam melhoria específica da capacidade de diagnóstico do CDC e aumento da vigilância.

Quanto à Categoria C estão os agentes de terceira maior prioridade; incluem agentes patogénicos emergentes que podem ser futuramente manipulados para disseminação 
em massa, devido à sua disponibilidade, facilidade de produção e disseminação; potencial para futura alta morbilidade e mortalidade e grande impacto sobre a Saúde Pública. Para informação complementar ver apêndice, NIAID Emerging Infectious Diseases/Pathogens

\section{Agentes Biológicos}

\section{Carbúnculo}

Segundo dados retirados do European Centre for Disease Prevention and Control (ECDC) (2009), o carbúnculo continua a ser uma doença rara na União Europeia (UE). Os casos continuam a ser esporádicos e a maioria associados à exposição ocupacional.

Em 2010 também apareceram novos casos em consumidores de drogas injetáveis, na Alemanha e em Portugal (em Coimbra), mas não se estabeleceu uma relação com os casos da Escócia, tendo por base a informação do ECDC.

Os casos de Portugal foram investigados, após realizarem uma avaliação dos dados clínicos e dos resultados das autópsias, concluíram que o carbúnculo não estaria na causa de morte dos toxicodependentes sinalizados.

Após intercâmbio de informação entre os diferentes países foi colocada de parte a possibilidade de Bioterrorismo.

O carbúnculo é uma doença aguda causada pelo Bacillus anthracis, um bacilo Gram-positivo, produtor de esporos, o que the permite ficar ativo só quando há condições adequadas. O nome "anthrakis" provém da palavra grega carvão, baseando-se na forma natural mais comum de ocorrência da doença - feridas escuras na pele. A doença existe há centenas de anos e ainda ocorre naturalmente, em animais e humanos, na Ásia e em algumas zonas da Austrália (Montoya, 2009).

Os EUA e a ex União Soviética têm armazenado o Bacillus anthracis. Os países que têm programas com agentes biológicos, aumentaram de 10 em 1989 para 17 em 1995; em 2007 não se sabe quantos países do mundo investigaram esta área (CDC, 2009c).

O carbúnculo ocorre com mais frequência em ovinos, caprinos e bovinos que ingerem os esporos do solo contaminado. Os Humanos ficam infetados através do contacto com a pele, ingestão ou inalação de esporos do Bacillus anthracis de animais infetados ou produtos desses animais (como a doença dos "tosquiadores" que estão sujeitos à exposição através do pêlo dos caprinos) como descreve Bossi (2004).

Segundo CDC (2009c), o período de incubação após exposição ao $B$. anthracis é de 1 dia a 8 semanas (em média 5 dias), dependendo da via de transmissão e da dose:
- 2-60 dias por exposição pulmonar;

- 1-7 dias por exposição cutânea;

- 1-7 dias por ingestão.

O esporo do B. anthracis é resistente. Como arma biológica pode ser utilizado como aerossol. As formas de transmissão do carbúnculo incluem: inalação de esporos, contacto cutâneo com esporos ou material contaminado e ingestão de alimentos contaminados como caracteriza Bossi (2004).

O contágio do carbúnculo pessoa a pessoa é pouco provável. 0 contágio por via aérea não ocorre, mas o contacto direto com as lesões da pele pode resultar numa infeção cutânea (WHO, 2009b).

A infeção humana por carbúnculo pode ocorrer sob três formas clínicas: pulmonar, cutânea e gastrointestinal, dependendo da via de exposição.

O tratamento precoce é fundamental. Para as três formas de doença, é necessária uma rápida avaliação médica e tratamento adequado. 0 carbúnculo responde bem à terapêutica antibiótica.

Quanto à prevenção da doença, existe uma vacina que não está aprovada para imunização em massa.

\section{Botulismo}

O botulismo é uma doença pouco comum na UE. A forma geralmente observada é o botulismo alimentar (ECDC, 2009).

Como refere Bossi (2004), a doença pode ter diversas designações, origens e formas de apresentação:

\section{Botulismo Alimentar}

É adquirido através da ingestão de alimentos contaminados com a toxina do Clostridium botulinum (ex ${ }^{\circ}$ enlatados em mau estado de conservação e enchidos caseiros). É a forma mais comum nos adultos. De notar que a presença de toxina nos alimentos não lhes altera $o$ aspeto nem o gosto. No mês de setembro de 2015 foram notificados três casos de botulismo alimentar, na região Norte de Portugal, confirmados laboratorialmente, não tendo sido registado nenhum óbito. Na sequência da investigação epidemiológica, ainda em curso, foi possível determinar que a origem destes casos de doença está associada à ingestão de produtos alimentares fumados, segundo DGS.

\section{Botulismo da Ferida}

Desenvolve-se quando as feridas ficam infetadas e o microrganismo tem condições ideais (anaerobiose) para se desenvolver e produzir a toxina. 


\section{Botulismo do Lactente}

Ocorre num pequeno número de crianças (geralmente com menos de 6 meses) que ingere o microrganismo e a toxina é produzida no seu intestino.

Em Bioterrorismo, a exposição à toxina do botulismo pode ocorrer sob as duas formas como agente biológico: através da aerossolização ou contaminação alimentar.

O período de incubação do botulismo de origem alimentar é de 12-36 horas após a ingestão; os sintomas de botulismo pulmonar iniciam-se 24-72 horas depois da exposição a aerossóis. No botulismo lactente o período de incubação é desconhecido (WHO, 2009c).

O botulismo transmite-se pela ingestão de toxina préformada nos alimentos contaminados (CDC, 2009d).

A aerossolização da toxina botulínica tem sido descrita e pode ser um mecanismo para Bioterrorismo, refere Bossi (2004).

0 botulismo não é transmitido pessoa a pessoa (CDC, 2009d).

Tendo em conta o que descrevem Bossi, et al. (2004) e CDC (2009d) o botulismo de origem alimentar é acompanhado de sintomas gastrointestinais, com diarreia inicial seguida de obstipação na fase mais grave. Inclui ainda secura das mucosas, tenesmo e retenção urinária. Ambos os tipos de botulismo partilham dos mesmos sintomas tal como:

- $\quad$ p paciente não apresenta febre;

- Consciência preservada;

- Neuropatia craniana simétrica (pálpebras caídas, dificuldade em deglutir ou falar ou fechar a boca);

- Visão turva e diplopia devido à paralisia dos músculos extra oculares;

- Relaxamento simétrico descendente num padrão distal para proximal (paralisia dos braços em primeiro lugar, seguido dos músculos respiratórios e depois as pernas);

- Disfunção respiratória devido à paralisia dos músculos respiratórios ou obstrução da via aérea superior devido ao relaxamento da glote;

- Não existem défices sensoriais.

O diagnóstico precoce é essencial. A antitoxina que só está indicada nos casos graves e com insuficiência respiratória, é eficaz na redução da gravidade dos sintomas, se administrada precocemente. Na terapêutica do botulismo merece particular importância o tratamento de suporte. Os doentes devem ser cuidadosamente monitorizados, particularmente no que diz respeito a sinais de gravidade. Quando a gravidade é moderada, há perigo de aspiração de vómito e dificuldade em formar o bolo alimentar, pelo que se deve colocar sonda nasogástrica e/ou instituir dieta líquida; surge o tenesmo urinário pelo que se deve algaliar e administrar laxantes para prevenir obstipação.

Peste

A OMS declara 1000 a 3000 casos por ano de Peste em todo o Mundo nas zonas rurais e em algumas áreas urbanas do sul da Ásia. Em média, 5 a 15 casos em cada ano ocorrem no Oeste dos EUA. A maioria dos casos é de peste bubónica. De uma forma natural a peste pneumónica é pouco comum, embora possam ocorrer pequenos surtos, segundo a OMS (WHO, 2009d).

Na Europa desde 2007 até 2011 não têm sidos declarados casos (ECDC, 2013).

A peste é uma doença bacteriana aguda causada por uma bactéria Gram-negativa, a Yersinia pestis. Existem várias formas de peste que, dependendo das circunstâncias, podem ocorrer separadamente ou em combinação: peste bubónica, peste pneumónica e Forma septicémica (CDC, 2009e).

O período de incubação da peste é normalmente 2-8 dias sendo inferior na exposição por via aérea (1-3 dias) (CDC, 2009e).

A peste normalmente é transmitida ao Homem por um vetor, a pulga infetada de roedores. A peste bubónica ocorre por picada de pulga infetada ou quando materiais contaminados com a bactéria entram no organismo, através da pele não íntegra.

A Yersinia pestis poderá ser transmitida, num ataque bioterrorista, sob a forma de aerossol. A peste pneumónica é transmitida pessoa a pessoa através de gotícula pelo mecanismo da tosse.

O CDC (2009e) recomenda que na peste pneumónica devem ser implementadas as precauções de gotícula, incluindo o uso de máscara para o profissional de saúde, até o doente ter completado 72 horas de antibioterapia. Os doentes com peste pneumónica devem ser colocados em isolamento respiratório.

Como o período de incubação pode ir até 8 dias, as pessoas em período de contágio podem, eventualmente, infetar outras pessoas. 0 controlo da doença seria então mais difícil, dependendo da área de deslocação (CDC, 2009e).

Esta bactéria é facilmente destruída pela luz solar, mas mesmo assim quando é lançada na atmosfera, pode sobreviver até uma hora.

0 risco de morte é elevado. Os antibióticos devem ser administrados dentro de 24 horas após os primeiros sintomas. Logo, no início da resposta a um ataque de 
Bioterrorismo, esses antibióticos seriam testados para determinar qual seria mais eficaz contra o agente em particular que foi usado (CDC, 2009e).

\section{Varíola}

Surtos de varíola ocorreram ao longo do tempo por milhares de anos, sendo o último caso declarado nos EUA em 1949; no Mundo foi na Somália em 1977. Em 1980, esta doença foi declarada erradicada pela OMS e a vacina foi retirada do plano de vacinação mundial pela mesma entidade (WHO, 2009a), no entanto foi reintroduzida em militares da primeira linha de combate ao Bioterrorismo.

A varíola é uma doença infeciosa grave e por vezes fatal, causada pelo vírus varíola (um Ortopoxvírus). Apesar, como referido anteriormente ter sido erradicada em 1980, continua a ser uma arma potencial de bioterrorismo, devido ao potencial de causar morbilidade grave, a população ser numa percentagem elevada não imune, e poder ser transmitida por via aérea. Um caso único neste contexto, é uma emergência em Saúde Pública, porque seria o resultado de um ato intencional.

O período de incubação da varíola é 7-17 dias, em média 12 dias (CDC, 2009f).

A varíola é transmitida pessoa a pessoa por via aérea, por gotícula e por contacto com as lesões da pele ou pelas secreções. Há maior risco de transmissão se os doentes tiverem tosse e/ou na forma hemorrágica da varíola.

Ao contrário da varicela, a qual é contagiosa antes do exantema aparecer, as pessoas com varíola podem transmitir a doença desde o início do exantema até à queda da última crosta (aproximadamente três semanas) explica o CDC (2009f).

Os sintomas da varíola são semelhantes a outras doenças víricas. As lesões da pele aparecem com um progresso rápido sequencial de máculas seguidas de pápulas, vesículas e crostas.

O mesmo autor enumera outros sintomas que ajudam a identificar, incluem:

- 2-4 dias de febre e mialgias não específicas;

- Lesões mais evidentes na face e nas extremidades (incluindo palmas das mãos e planta dos pés) em contraste com a distribuição centrípeta da varicela;

- Existência de crostas a partir da primeira semana;

- $\quad$ Em contraste com a varicela, as lesões estão todas no mesmo estádio.

Não há tratamento específico para a varíola mas têm sido testados antivíricos.
Tularémia

Segundo dados retirados do ECDC (2009), o grande número de casos declarados em 2007 foi devido aos surtos em Espanha. Habitualmente é mais referida nos países escandinávos.

A Francisella tularensis é uma bactéria Gram-negativa, que pode ser encontrada na água e solo contaminados, em artrópodes (carraças, mosquitos ou moscas), animais selvagens (coelhos, lebres, esquilos, almíscares, castores) e, ocasionalmente, animais domésticos (ovelhas, cães ou gatos). A tularémia é conhecida pela febre dos coelhos. O Humano pode ser infetado de várias formas, incluindo picada de artrópode, manuseamento de tecidos e/ou fluídos de animais infetados, contacto direto ou ingestão de água, alimentos ou solo contaminado e inalação de aerossóis (CDC, 2009g).

Atularémia tem várias formas diferentes de apresentação, dependendo da via de inoculação, nomeadamente: pele e mucosas, olhos, trato gastrointestinal e respiratório.

O período de incubação é aproximadamente 3-5 dias mas pode variar de 1 a 25 dias (CDC, 2009g).

A transmissão pessoa a pessoa não está documentada, por isso não é necessário o isolamento das pessoas infetadas segundo a OMS (WHO, 2009e).

O período de contágio é desconhecido.

Os principais sintomas são: febre súbita, arrepios, cefaleias, mialgias, artralgias, tosse seca, fraqueza progressiva, úlcera na orofaringe, náuseas, diarreia e vómitos.

Todos os autores consultados referem que as pessoas expostas devem ser tratadas o mais rapidamente possível, uma vez que a doença pode ser fatal, se não for tratada com os antibióticos apropriados. A bactéria pode ser encontrada no sangue durante as primeiras 2 semanas da doença, e nas lesões até 1 mês, se não houver tratamento adequado.

\section{Febres Hemorrágicas (FH)}

As $\mathrm{FH}$, referindo que são um grupo de doenças originadas por várias distintas famílias de vírus: arenavírus, filovírus, bunyavírus e flavivírus. Vários surtos desta doença tem surgido em África, contudo o mais grave que está descrito é o que inicio em 2014 na serra Leoa que se mantém ainda a Outubro de 2015, em menor dimensão mas ainda se mantém o alerta mundial. Este surto teve impacto a nível mundial visto que houve casos confirmado em vários países entre os quais Espanha e EUA. A 20 de Outubro de 2015 estavam confirmados um total de 28540 casos, sendo 15242 confirmados laboratorialmente e com 11313 mortes, dados fornecidos pela OMS. 
0 período de incubação, em geral é 1-21 dias (CDC, 2009h).

Os vírus das $\mathrm{FH}$ mantêm-se na natureza à custa dos hospedeiros de manutenção (roedores, carraças e insetos), podem ter hospedeiros de ligação (aves), de amplificação (vertebrados) e acidentais (Homem).

O contágio ao Homem está associado a alterações no meio ambiente (construções de barragens - aumento de mosquitos), facilidade do contacto entre os portadores e o Homem (limpeza da floresta, trabalhos agrícolas, reconstrução de casas - contacto com ratos e seus excrementos), Invernos rigorosos (aumento de ratos), indústria biológica (preparação de vacinas) e transmissão hospitalar.

O período de contágio não está estabelecido, mas poderá haver transmissão do vírus assim que a pessoa esteja sintomática.

O CDC (2009h) enumera os sinais e sintomas característicos das $\mathrm{FH}$, que variam consoante o tipo de vírus. Existem sinais e sintomas iniciais semelhantes como febre alta, mialgias, manifestações digestivas e mais tarde, os doentes que constituem casos graves apresentam as manifestações hemorrágicas, alterações hemodinâmicas, insuficiência renal, pulmonar e/ou neurológica com falência multiorgânica.

De uma maneira geral, não há tratamento ou cura estabelecida para a $\mathrm{FH}$, a não ser o tratamento intensivo de suporte. Contudo existem estudos laboratoriais a decorrer para que se consiga uma vacina. Já há testes a serem implementados para a Doença por vírus Ébola.

\section{Impacto do Bioterrorismo}

Catástrofe, como já foi referido anteriormente, é uma destruição severa que excede em muito a capacidade de resposta e os recursos psicossociais da comunidade afetada (Weisaeth (1995) citado por Cunha (2005)).

Segundo Raphael (1993) igualmente referenciado por Cunha (2005), as catástrofes podem ser avaliadas quanto:

- Número de mortes;

- Número de pessoas feridas ou afetadas;

- Destruição ou deslocação de casa, vizinhança ou comunidade;

- Danos económicos e sociais de uma comunidade;

- Nível de destruição da comunidade afetada.

Estes acontecimentos surgem sempre inesperadamente e são assustadores para os afetados. Aqueles que foram diretamente expostos falam sempre de como as suas vidas mudaram radicalmente. Descrevem um estado de confusão, ansiedade generalizada e desamparo. As vítimas de catástrofes referem que "as coisas deixaram de ser como eram", falam do seu sentimento de insegurança e da sua capacidade de contar com a estabilidade do seu ambiente ter sido perdida. Alguns referem que se sentem impotentes de terem perdido a estrutura da sua vida quotidiana. Há estudos sobre o efeito das catástrofes que indicam que este tipo de evento afeta a vida das pessoas por anos e mesmo décadas (Cunha, 2005).

O NATIONAL RESEARCH COUNCIL (2002) citado por Cunha (2005) salienta o facto de para além de um ataque de Bioterrorismo ser uma catástrofe, ainda tem o facto de ser um ato terrorista, é uma consequência da maldade humana, da violência ou da guerra; é ilegal ou ameaça o uso da força ou de violência para coagir as sociedades ou governos, induzindo o medo nas populações, envolvendo motivações ideológicas e políticas.

A meta de um ato terrorista é induzir num estado de incerteza psicológica, vulnerabilidade pessoal e medo, a morte e a destruição. Os medos da guerra psicológica usada pelo terrorista que se orienta em desencadear uma grave perturbação de ordem social. As reações psicológicas que se seguem aos ataques terroristas são mais intensas e mais prolongadas que as reações psicológicas que se seguem aos desastres naturais (Cunha, 2005).

A mesma autora escreveu que um ataque biológico pode provocar: impacto social, risco de fadiga, calor e stress de isolamento devido à necessidade de utilizar equipamento de proteção individual. 0 processo até as pessoas ficarem doentes e receberem a imunização necessária pode ser stressante. A ameaça súbita, inesperada e desconhecida para a saúde, não tendo pistas sensoriais, é prolongada e/ ou recorrente. $O$ agente utilizado no ataque é geralmente contagioso e produz vítimas que são observadas pelos outros; medo, pânico e somatização dos sintomas. Surgem respostas psicológicas devido ao medo dos agentes “invisíveis” e da contaminação.

Zuckerberg (2003) citado por Álamo (2004), refere que devido às consequências desastrosas do 11 de Setembro de 2001, a gestão do stress traumático adquiriu uma importância crescente nos locais de trabalho. Seis meses depois deste dia, mais de $60 \%$ dessas tais pessoas em que se diagnosticou Stress Pós-traumático referiram que tinham alterações de humor intensas relacionadas com o trauma como náuseas, dor e depressão. A hipervigilância no trabalho e as discórdias familiares encontram-se entre os efeitos negativos, embora se note que a coesão do grupo e o empenho são consequências positivas de quem sobreviveu a um atentado terrorista.

Um ataque bioterrorista para além de afetar a nível físico e psicológico o ser Humano, pode afetar uma comunidade a nível social, económico e ambiental (INTERPOl, 2009). 
Com o 11 de Setembro de 2010 confirmou-se que o pânico generalizado e a despesa precipitada em cuidados de saúde marcaram de forma evidente a microeconomia. Também ao nível da macroeconomia, a falta de confiança dos consumidores levou ao decréscimo do investimento com consequente queda generalizada dos mercados financeiros e também uma diminuição do número de viagens. Contudo as empresas farmacêuticas têm um acréscimo na sua produção, devido à procura de antibióticos e antidepressivos (Bandeira, 2006).

Cevallos (2001) escreveu sobre a paranóia bioterrorista que tomou conta da América Latina, na segunda semana de Outubro de 2001 , onde a maioria dos governos adotou medidas de precaução, embora vários acontecimentos relacionados ao carbúnculo não tenham passado de brincadeiras. No Brasil, um avião com destino à Alemanha ficou retido, depois de se encontrar "Pó branco" no seu interior. Na Argentina, um estranho "Pó branco" foi encontrado em envelopes utilizados nas eleições legislativas. Os trabalhadores de um observatório astronómico no Chile, que têm sociedade com instituições científicas dos Estados Unidos, também receberam uma carta com "Pó branco" com os dizeres "Djihad" (Guerra Santa). As análises demonstraram que era uma brincadeira. Os falsos alarmes não dissiparam os temores e os países não menosprezaram o assunto. No México o debate sobre o assunto é amplo e o governo criou uma comissão especial para investigar e prevenir possíveis ataques. Além disso, as autoridades deram a 113 hospitais a missão de serem "vigias" para detetar casos de carbúnculo. A OMS, perante este cenário, advertiu que os governos preparassem planos de atuação, e referiu que a melhor arma contra um ataque é ter um adequado Sistema de Saúde Pública.

A abordagem e tratamento das vítimas de Bioterrorismo implica uma investigação epidemiológica, profilaxia, e medidas de prevenção e tratamento médico. 0 diagnóstico como já foi referido é difícil de fazer.

A triagem de um evento com multivítimas é bastante diferente dos procedimentos em situação normal, no pré-hospitalar ou mesmo no SU.

Como refere Soller et al. (2008), objetivo principal da triagem é a rápida avaliação da vítima que necessita de cuidados emergentes, determinar a gravidade da lesão ou doença e a necessidade correspondente de cuidados de emergência.

O propósito da triagem de catástrofe é diferente: tenta atribuir os recursos existentes para abranger o maior número de vítimas. Vários métodos foram evoluindo e adaptando para triar grande número de vítimas como escreve Soller et al. (2008), por ex. ${ }^{\circ}$ Triagem codificada por cores, START - Simple Triage and Rapid Treatment.
Um dos métodos utilizados no Bioterrorismo, como salienta Henretig (2002), é baseado no modelo de abordagem clínica do Advanced Trauma Life Support (ATLS): os profissionais que recebem as vítimas podem também usar o algoritmo para despistar um possível ataque bioterrorista. A avaliação primária é baseada no método $A B C D E$ como se pode constatar na TABELA I, seguida da avaliação secundária (TABELA II).

Taylor e Frazer (1981), citado por Cunha (2005), classificam as vítimas em vários níveis:

- Vítimas principais, estão diretamente expostas. São as pessoas da linha da frente, que tiveram o máximo de exposição ao ato;

- Vítimas secundárias, são os parentes e amigos das vítimas principais que vivem sob angústia dos seus familiares estarem expostos;

- Vítimas nível 3, são as equipas de resgate que necessitarão de ajuda para manter a sua eficiência no desempenho das suas funções e depois para fazer face aos efeitos psicológicos;

- Vítimas nível 4, a comunidade envolvida no ato terrorista, incluindo os que convergem, os que se oferecem para ajudar, os que partilham a dor e a perda ou os que, de alguma maneira, têm alguma responsabilidade;

- Vítimas nível 5, pessoas que não estão envolvidas diretamente mas sofrem com as consequências globais. Pessoas que podem ter experienciado momentos de angústia e perturbação. Pode existir este tipo de vítimas em qualquer parte do mundo devido ao impacto global do terrorismo;

- Vítimas nível 6, as pessoas que por acaso teriam sido as vítimas principais mas não chegaram a ser, estão indireta ou diretamente envolvidas.

Álamo (2004) refere que não se podem esquecer os pais de crianças pequenas, os familiares das equipas de primeira intervenção, as próprias equipas de primeira intervenção, as equipas médicas e as pessoas que se encontram em quarentena e em isolamento.

As consequências da utilização de armas biológicas podem ser a curto e a longo prazo. Como descrevem Pires e Silva (2009), a curto prazo ocorre quando o efeito mais proeminente da utilização das armas biológicas é o grande número de vítimas imediatas que podem causar. Para além disso, o enorme empenho dos recursos médicos e de infraestruturas necessários, pode ainda ter que ser ampliado pelo facto da reação psicológica de uma população civil a um ataque biológico ser normalmente mais grave do que a reação a um ataque com armas convencionais. Esta reação 
TABELA I - Algoritmo para despiste de possível ataque bioterrorista.

TABLE I - Algorithm to identify possible bioterrorist attack.

Em itálico indica a adição ao paradigma convencional

\begin{tabular}{|c|c|}
\hline \multicolumn{2}{|r|}{ AVALIAÇÃO PRIMÁRIA } \\
\hline Mnemónica & Avaliação/Interpretação e Acção* \\
\hline$A$ & $\begin{array}{l}\text { Via Aérea com estabilização da coluna cervical } \\
\text { - Avaliação dos movimentos respiratórios, estridor, etc. } \\
\text { - Entubação orotraqueal, cricotirotomia, etc. }\end{array}$ \\
\hline B & $\begin{array}{l}\text { Respiração } \\
\text { - Avaliação da coloração, frequência respiratória, oximetria de pulso, etc. } \\
\text { - Suporte ventilatório: boca-boca, máscara facial com insuflador manual, Tubo orotraqueal } \\
\text { com insuflador manual, etc. }\end{array}$ \\
\hline C & $\begin{array}{l}\text { Circulação } \\
\text { - Avaliação da frequência cardíaca, perfusão vascular, preenchimento capilar, pulsos, pressão } \\
\text { sanguínea, monitorização cardíaca. } \\
\text { - Compressões cardíacas, acesso endovenoso, fluidoterapia, etc. }\end{array}$ \\
\hline $\mathrm{D}$ & $\begin{array}{l}\text { Disfunção neurológica } \\
\text { - } \quad \text { Avaliação da resposta à estimulação, tamanho e reatividade das pupilas. } \\
\text { - Considerar entubação orotraqueal, hiperventilação para situações de compromisso grave. }\end{array}$ \\
\hline$E$ & $\begin{array}{l}\text { Exposição da vítima/Avaliação do ambiente por hipo ou hipertermia } \\
\text { - Despida, avaliação da temperatura } \\
\text { - } \quad \text { Arrefecimento ou aquecimento. } \\
\text { Epidemiologia } \\
\text { - História de exposição - "nuvem" visível, aviso de dispersão, explosão, ameaça conhecida, } \\
\text { - etc.? } \\
\text { - Números epidémicos" de vítimas com inicio agudo? } \\
\text { (Se positivo, considerar um ataque de Bioterrorismo - realizar a exame secundário.) }\end{array}$ \\
\hline
\end{tabular}

Fonte: Henretig (2002). Source: Henretig (2002).

pode, mesmo, incluir terror e/ou pânico. Deste modo, é essencial combinar estratégias de suporte psicológico com comunicações do risco real das populações, sempre que estiver presente uma possível exposição a estas armas.

As mesmas autoras referem ainda que as possíveis consequências a longo prazo causadas por agentes biológicos são mais incertas e menos bem compreendidas, podendo incluir doenças crónicas (como bronquite ou pneumonia) e efeitos retardados (por exemplo carcinogénese). Para além disso, certas doenças 
RISCOS - Associação Portuguesa de Riscos, Prevenção e Segurança

TABELA II - Avaliação secundária específica.

TABLE II - Specific secondary assessment.

\begin{tabular}{|c|c|c|}
\hline Passo & Mnemónica & Avaliação/Interpretação e Acção \\
\hline 1 & A & Antecipar um evento com armas biológicas (reconhecimento dos padrões, múltiplos casos, etc.) \\
\hline 2 & B & $\begin{array}{l}\text { "Be Careful" (questões de proteção do pessoal) } \\
\text { - } \quad \text { Precauções padrão para a maioria dos cenários; } \\
\text { - } \quad \text { Em caso de dúvida, usar máscara e proteção das membranas e mucosas. Se sabe } \\
\text { que é Peste, FH ou Varíola, usar as medidas indicadas em } \mathrm{E}_{1} \text {. }\end{array}$ \\
\hline 3 & C & Continuar com suporte de vida. \\
\hline 4 & D & Descontaminação, isolamento das vítimas como precaução. \\
\hline 5 & $D_{2}$ & $\begin{array}{l}\text { Diagnóstico } \\
\text { - História - acuidade do inicio, história da exposição, múltiplas vítimas, febre, } \\
\text { sintomas respiratórios, neurológicos ou dermatológicos. } \\
\text { - Exame físico - sinais vitais: aspetos cardiorespiratórios, neurológicos e } \\
\text { dermatológicos. } \\
\text { - Testes de laboratório - radiografia torácica, hemograma, estudos da coagulação. } \\
\text { - Possíveis diagnósticos. }\end{array}$ \\
\hline 6 & $\mathrm{D}_{3}$ & Tratamento (medicamentos) \\
\hline 7 & $\mathrm{E}_{1}$ & $\begin{array}{l}\text { Controlo da Infeção Epidémica: } \\
\text { - } \quad \text { Peste: Precauções de gotícula. } \\
\text { - } \quad \text { FH: Precauções de contacto e gotícula, considerar precauções de via aérea. } \\
\text { - Varíola: Precauções de via aérea. } \\
\text { - Outras Precauções universais. }\end{array}$ \\
\hline 8 & $\mathrm{E}_{2}$ & Comunicação da Epidemia às Forças da Lei e às entidades da Saúde Pública. \\
\hline 9 & $\mathrm{E}_{3}$ & Investigação Epidemiológica. \\
\hline 10 & $\mathrm{E}_{4}$ & Educar a população. \\
\hline
\end{tabular}

Fonte: Henretig (2002). Source: Henretig (2002)

- As sequelas orgânicas e os transtornos mentais, por exemplo. A psicose orgânica, o delírio, a demência entre outros;

- A exposição a qualquer elemento que possa provocar stress, seja de origem natural ou humano, é um fator de risco para os problemas sociais e mentais a longo prazo (incluindo a preocupação e transtornos a nível emocional);

- 0 medo dos ataques biológicos e químicos poderem estar relacionados com epidemias;

- 0 mito do pânico como crença popular difundida pelos meios de informação, apesar de haver estudos que referem que no caso de ataques NRBQ (Nuclear, Radiológico, Biológico e Químico) é pouco comum o pânico público; este só se verificaria se houvesse uma grande concentração de pessoas em espaços reduzidos, em vias de evacuação ou insuficientes ou que se encontrassem fechadas.

- O fornecimento de informações precisas e a partir de fontes idóneas é importante para diminuir a angústia. A OMS indica que, mal se saiba qual o agente, se deve avisar as equipas, pois assim estas poderão adequar a sua atuação ao agente em causa (Álamo, 2004). 
Equipamento de Proteção Individual (EPI) e Medidas de Precauções Adicionais

\section{Equipamento de Proteção Individual}

Os agentes de Bioterrorismo, geralmente não são transmitidos pessoa a pessoa e a re-aerossolização destes agentes é improvável. Todos os doentes nas Unidades de Saúde, incluindo os doentes sintomáticos com suspeita ou confirmação de doença relacionada com Bioterrorismo, devem ser abordados utilizando as precauções padrão. Para algumas doenças ou síndromas como a varíola e as $\mathrm{FH}$, devem ser utilizadas precauções adicionais necessárias, de maneira a reduzir a probabilidade de transmissão; estas referências foram citadas por English et al. (1999).

Não se deve desvalorizar a limpeza da unidade do doente e todo o equipamento que esteve em contacto com este ou então rejeitar o que for descartável.

Segundo English et al. (1999) as precauções padrão são utilizadas nas instituições de saúde para reduzir a transmissão de infeções de fontes reconhecidas ou não. Servem também para prevenir o contacto direto com os fluídos corporais (incluindo sangue), secreções, pele e mucosas não intactas.

Nas precauções padrão estão incluídas (English et al., 1999):

- $\quad$ Lavagem de mãos;

As mãos devem ser lavadas depois de se retirar as luvas, entre os cuidados às vítimas, quando apropriado para evitar as infeções cruzadas e sempre que, acidentalmente, se suje as mãos com sangue ou outro fluído corporal ou se esteja em contacto direto com a pessoa infetada ou supostamente infetada.

- Uso de luvas;

As luvas não necessitam de ser esterilizadas mas devem estar limpas. Devem ser utilizadas quando se manipula sangue e outros fluídos corporais, secreções ou qualquer objeto contaminado. Devem ser usadas luvas imediatamente antes de tocar em mucosas ou pele não intacta. Devem ser trocadas sempre entre procedimentos na mesma pessoa e após o contacto com material que possa estar contaminado. As luvas devem ser removidas logo após a sua utilização, antes de tocar em objetos ou superfície não contaminados e antes do contacto com outras vítimas. Deve ser relevado que as mãos devem ser lavadas imediatamente após retirar as luvas.

- Uso de máscara cirúrgica e proteção ocular;
Está indicada a utilização de máscara e proteção ocular ou de uma máscara com viseira para proteção das mucosas da boca, nariz e olhos, em procedimentos com potencial capacidade de produção de salpicos ou aerossóis de sangue, de fluídos corporais ou de secreções.

- Uso de bata;

A bata não necessita de ser esterilizada mas deve estar limpa. Deve-se usar bata para proteção da pele e para impedir a contaminação da roupa durante procedimentos com potencial capacidade de produção de salpicos ou aerossóis de sangue, de fluídos corporais ou de secreções. Deve-se selecionar a bata mais adequada à atividade e à quantidade de líquido provável.

Segundo os autores do Pre hospital Trauma Life Support (PHTLS, 2012), os EPI's estão divididos nos seguintes níveis:

\section{- Nível A}

Este nível oferece o mais alto nível de protecção das vias respiratórias e pele. As vias respiratórias são protegidas por aparelhos respiratórios, que fornece ar ao profissional através de pressão positiva. Este EPI "encapsula" o profissional e protege totalmente a pele e mucosas de agentes químicos.

\section{- $\quad$ Nível B}

Este nível oferece o mesmo nível de protecção das vias respiratórias mas um nível mais baixo de protecção da pele. 0 equipamento é resistente a salpicos de agentes químicos.

\section{- $\quad$ Nível C}

A protecção da pele é equivalente ao nível $B$, contudo a protecção das vias respiratórias é feita através de filtros adaptados a uma máscara e poderá estar associado um sistema de renovação de ar eléctrico.

\section{- Nível D}

Este nível oferece o nível mínimo de protecção, corresponde ao vestuário habitual de trabalho e pode incluir bata, luvas e máscara cirúrgica; tendo em conta os riscos associados.

A cada nível deve ser ainda avaliada a classe do EPI, na qual é testada e certificada o processo de proteção. Em situações de Bioterrorismo, o EPI é selecionado tendo em conta o tipo de agente, o meio em que foi lançado e a proximidade com a ameaça e deve cumprir a classe 4 , segundo o NIOSH (2008). 
É sempre difícil definir a Zona quente ou sinistro (Zona de perigo), visto que não é estática e as vítimas poderse-ão deslocar; a direção do vento também pode alterar a zona quente. Mediante estas condições, foi definido que para os profissionais do pré hospitalar o nível mais adequado será o Nível $\mathrm{A}$. Contudo devido a não ser um equipamento confortável e provocar exaustão deverse-á ajustar a cada situação.

\section{Medidas de Precauções Adicionais}

Mediante referência do CDC (2003b), as pessoas que foram vítimas de um ataque por um agente biológico poderão ficar em quarentena ou em isolamento, dependendo do tipo de exposição.

Entende-se por quarentena a restrição de atividades ou limitação da liberdade de movimentos daquelas pessoas que se presume que estiveram expostos a determinada doença e será uma forma de prevenir o contacto com aquelas que não estiveram. Esta pode ser realizada na própria habitação da pessoa.

Isolamento é a separação de uma pessoa ou de um grupo de pessoas de outras pessoas para evitar a propagação da infeção.

As precauções básicas devem ser utilizadas adicionalmente às medidas de precauções adicionais.

Segundo referência do CDC (2015), existem vários tipos de medidas de precauções adicionais, de acordo com o meio de transmissão:

\section{- Por contacto}

Por contacto direto, ocorre quando há transferência de microrganismos resultantes do contacto físico direto entre uma pessoa colonizada ou infetada e um hospedeiro suscetível; por contacto indireto quando implica a transferência passiva de microrganismos a um hospedeiro suscetível através de um "objeto ou superfície" intermediário, por exemplo as mãos contaminadas que não foram lavadas entre doentes. A vítima deverá ser internada, preferencialmente em quarto individual. Quando não for possível, deverá ser colocada num quarto com pessoas que tenham uma infeção ativa pelo mesmo agente, mas sem outra infeção.

- Por gotícula

Quando a transmissão se faz através de gotículas respiratórias expelidas a curta distância (<1metro) pela tosse, espirro, fala e procedimentos como aspiração de secreções e broncoscopias. As gotículas não permanecem suspensas no ar. A vítima deverá ser internada, preferencialmente em quarto individual. Quando não for possível, deverá ser colocada num quarto com pessoas que tenham uma infeção ativa pelo mesmo agente, mas sem outra infeção. Quando isto também não for possível dever-se-á manter uma distância mínima de 1,5 metros entre a vítima infetada e os outros doentes. Não são necessários sistemas especiais de ventilação. Para além das precauções padrão e para o uso de máscara, esta deve ser usada sempre que se permanecer a menos de 1 metro da vítima.

- Por via aérea

Quando a transmissão se faz por pequenas partículas $(\leq 5 \mu \mathrm{m})$ que permanecem suspensas no ar durante longos períodos e podem ser disseminadas à distância através de correntes de ar. A vítima deverá ser colocada num quarto com pressão negativa relativamente às áreas vizinhas, sendo a exaustão feita para o exterior, passando antes por filtros de alta eficiência. A porta do quarto deverá estar sempre fechada. Quando não for possível, deverá ser colocado num quarto com pessoas que tenham uma infeção ativa pelo mesmo agente, mas sem outra infeção. As pessoas que terão de entrar no quarto terão de usar respiradores (tipo P1/ P2, segundo norma europeia ou N95 segundo norma americana).

\section{Entidades Nacionais Relevantes no Combate ao Bioterrorismo}

A atuação numa situação de Catástrofe envolve várias entidades e vários agentes da PC, como por exemplo Corpos de Bombeiros, Instituto Nacional de Emergência Médica (INEM), Polícia de Segurança Pública (PSP), entre outras.

Na Lei $n^{\circ}$ 27/2006 de 03 de Julho, a Lei de Bases da Proteção Civil, no $n^{\circ} 1$ do $\operatorname{Art}^{\circ}{ }^{4} 46^{\circ}$, identifica os agentes de PC: os Corpos de Bombeiros, as Forças de Segurança, as Forças Armadas, as Autoridades Marítimas e Aeronáuticas, o INEM e demais Serviços de Saúde e os Sapadores Florestais; cada um com as suas atribuições.

Estes agentes que podem colaborar com outras entidades, articulam-se operacionalmente nos termos do Sistema Integrado de Operações de Proteção e Socorro (SIOPS) definido como o conjunto de estruturas, de normas e procedimentos que asseguram que todos os agentes da PC atuam, no plano operacional, articuladamente sob um comando único, sem prejuízo da respetiva dependência hierárquica e funcional, regulamentado pelo Decreto-lei $n^{\circ} 134 / 2006$ de 25 de Julho. 
Segundo a Lei de Bases, a PC "é a atividade [...] com a finalidade de prevenir riscos coletivos inerentes a situações de acidente grave ou catástrofe, de atenuar os seus efeitos e proteger e socorrer as pessoas e os seus bens em perigo quando aquelas situações ocorram".

\section{Forças Armadas Portuguesas}

As Forças Armadas têm como uma das suas missões "colaborar em missões de Proteção Civil e em tarefas relacionadas com a satisfação das necessidades básicas $e$ melhoria da qualidade de vida das populações", segundo a Lei Orgânica n 1-A/2009 de 7 de Julho (Lei Orgânica de Bases da Organização das Forças Armadas).

As Forças Armadas Portuguesas têm acumulado experiência no domínio das ameaças nucleares, biológicas e químicas, através do seu grupo de intervenção. Estas competências acumuladas, bem como as capacidades que vêm sendo desenvolvidas, habilitam as Forças Armadas a assumir um papel decisivo na resposta nacional ao Bioterrorismo. Têm equipamento de deteção, proteção e de descontaminação, bem como um Hospital de Campanha, entre outro equipamento específico.

\section{Autoridade Nacional de Proteção Civil (ANPC)}

Segundo o Decreto-lei $n^{\circ} 75 / 2007$ de 29 de Março (Lei Orgânica da ANPC), no $n^{\circ} 1$ do $\operatorname{Art}^{\circ}{ }^{\circ} 2^{\circ}$, esta tem a missão de "planear, coordenar e executar a política de proteção civil, designadamente na prevenção e reação a acidentes graves e catástrofes, de proteção e socorro de populações e de superintendência da atividade dos Bombeiros".

Tem diversas atribuições quanto ao planeamento e emergência entre as quais, no $\mathrm{n}^{\circ} 3$ alínea a) do mesmo artigo, "contribuir para a definição da política nacional de planeamento e de emergência, elaborar diretrizes gerais, promover a elaboração de estudos e planos de emergência e facultar apoio técnico e emitir parecer sobre a sua elaboração por entidades setoriais".

A 11 de Dezembro foi tornado público através da Resolução de Conselho de Ministros $n^{\circ}$ 87/2013, a aprovação do Plano Nacional de Emergência de Proteção Civil (PNEPC). Este plano é um instrumento de suporte às operações de proteção civil em caso de iminência ou ocorrência de um acidente grave ou catástrofe em Portugal, tendo por base a Lei de Bases.

Alguns Corpos de Bombeiros, nomeadamente os Bombeiros Voluntários de Santa Maria da Feira e o Regimento de Sapadores Bombeiros de Lisboa, têm equipamentos e viaturas especificamente direcionadas para intervir em situações de matérias perigosas e nomeadamente em Bioterrorismo, com equipas com formação específica, assim como a Força Especial de Bombeiros ("os Canarinhos").
Instituto Nacional de Emergência Médica (INEM)

O INEM tem por missão "definir, organizar, coordenar, participar e avaliar as atividades e o funcionamento de um Sistema Integrado de Emergência Médica (SIEM) de forma a garantir aos sinistrados ou vítimas de doença súbita a pronta e adequada prestação de cuidados de saúde”, segundo o Decreto-lei n²20/2007 de 29 de Maio (Lei Orgânica do INEM).

Segundo o mesmo diploma, tem diversas atribuições entre as quais: "assegurar a elaboração de planos de emergência/catástrofe em colaboração com a Administração Regional de Saúde e com a ANPC" $e$ também "orientar a atuação coordenada dos agentes de saúde nas situações de catástrofe ou calamidade, integrando a organização definida nos planos de emergência/catástrofe".

O INEM tem equipamento de atuação em catástrofes, nomeadamente Postos Médicos Avançados, Hospital de Campanha, EPI específicos para situações que envolvam matérias perigosas, Viatura de Intervenção em Catástrofe e profissionais com formação, capazes para intervir nesta área.

Polícia Judiciária (PJ) - Unidade Nacional ContraTerrorismo

A Unidade Nacional Contra-Terrorismo, é um grupo de intervenção da Polícia Judiciária (PJ), tem como missão: “coadjuvar as autoridades judiciárias na investigação, desenvolver e promover as ações de prevenção, deteção e investigação da sua competência ou que lhe sejam cometidas pelas autoridades judiciárias competentes", definido no $\mathrm{n}^{\circ} 1$ do Art. $^{\circ} 2^{\circ}$ da Lei $n^{\circ} 37 / 2008$ de 06 de Agosto (Lei orgânica da PJ). As atribuições são prevenção e deteção criminal, investigação criminal, entre outras.

Guarda Nacional Republicana (GNR) - Grupo de Intervenção de Proteção e Socorro (GIPS)

O GIPS foi criado na dependência do Comando-Geral da Guarda Nacional Republicana (GNR).

Tem como missão, segundo o Decreto-lei n 22/2006 de 02 de Fevereiro, "executar ações de prevenção e de intervenção de primeira linha em todo o território nacional, em situações de emergência de proteção e socorro, designadamente nas ocorrências de incêndios florestais ou matérias perigosas, catástrofes ou acidentes graves".

Têm equipamento e viaturas especificamente direcionadas para intervir em situações de matérias perigosas e nomeadamente em Bioterrorismo, com equipas com formação específica. 
Polícia de Segurança Pública (PSP) - Centro de Inativação de Explosivos e Segurança em Subsolo (CIEXSS)

O CIEXSS é uma subunidade da Unidade Especial da PSP, possui um núcleo de direção e formação técnica de especialidade de deteção e inativação de engenhos explosivos e de segurança no subsolo, estando também habilitados para atuarem em situações de matérias perigosas.

Tem como missão principal, sendo uma força da PSP, "proteger, socorrer e auxiliar os cidadãos e defender e preservar os bens que se encontram em situações de perigo, por causas provenientes de ação humana ou da natureza", segundo a Lei n 53/2007 de 31 de Agosto (Lei Orgânica da PSP).

\section{Plano de Emergência Hospitalar (PEH)}

Um PEH pode ser definido como um conjunto de ações a realizar ordenadamente para dar resposta a uma situação catastrófica em que o hospital se veja envolvido. Estas situações têm duas vertentes, consoante o local onde tem lugar a catástrofe. Com efeito, esta poderá ocorrer fora do hospital, sem o afetar, definindo-se como Emergência Externa, ou atingi-lo, e nesse caso trata-se de uma Emergência Interna, portanto o Plano de Emergência é constituído por dois documentos: Plano de Emergência Externo (PEE) e o Plano de Emergência Interna (PEI) (Alves, 1999 In: Marques e Sousa, 2004).

Os hospitais têm que estar preparados para atender vítimas de acidentes graves ou de catástrofes (de origem natural, tecnológica ou social) que ocorram na sua área de influência e na dos hospitais que apoiam e servem de base.

A capacidade de dar resposta eficazmente a uma ocorrência deste tipo dependerá da preparação dos profissionais do Hospital, refere Shultz et al. (2002).

Para a realização dos planos de emergência, como indica Shultz et al. (2002), é necessário elaborar a carta de riscos mais previsíveis na área de influência do hospital e nas quais ele apoia e serve de base. Inventariar os meios e recursos internos disponíveis, de reforço e a disponibilizar. Com o objetivo de estabelecer critérios para a sua atuação, evitando ou, no mínimo, reduzindo a mortalidade e morbilidade das vítimas.

Mediante esta primeira avaliação, poderá ser necessário a elaboração de Planos Especiais. Definem normas e medidas de atuação e de auto-proteção para outros riscos - sismos, intempéries, inundações e ações conflituosas, terroristas ou subversívas. Estes planos também podem ser denominados de Planos de Contingência Hospitalar (PCH).
A resposta hospitalar deve ser:

- Incorporada num plano geral de resposta a emergências e catástrofes;

- Apoiar-se nas organizações, estruturas e operações internas;

- Integrada com outras instituições externas (préhospitalar e hospitalar, incluindo hospital móvel).

O PCH consiste num conjunto de medidas e ações que deverão ser aplicadas oportunamente, de modo articulado, em cada fase da evolução do incidente e tem como objetivo manter a atividade, apesar do absentismo laboral esperado durante o período de maior expressão (Ferreira, 2006).

Há autores que defendem que um plano é um processo de planeamento antecipado, incluindo avaliação dos riscos e vulnerabilidades, estabelece prioridades e desenvolve os procedimentos para mitigar e responder a uma situação de catástrofe (Schultz et al., 2002).

Estes autores escrevem que os planos contingência/ especiais deverão reportar os PE (Interna e Externa) e conter:

- $\quad$ A tipificação dos riscos;

- $\quad$ As medidas de prevenção a adotar;

- A identificação dos meios e recursos mobilizáveis;

- A definição das responsabilidades que incubem aos organismos, serviços e estruturas, públicas ou privadas, com competências no domínio da PC;

- Os critérios de mobilização e mecanismos de coordenação dos meios e recursos, públicos ou privados, utilizáveis;

- A estrutura operacional que há-de garantir a unidade de direção e o controlo permanente da situação.

Os PEH e os PCH estão sujeitos a atualização periódica e devem ser objeto de exercícios frequentes com vista a testar a sua operacionalidade (HSJ, 2004). Há autores que recomendam duas vezes por ano (Shultz et al., 2002).

\section{Plano de Contingência para o Bioterrorismo}

As infraestruturas de Saúde Pública devem estar preparadas para a prevenção das doenças e dos danos que poderão resultar de ataques de terrorismo biológico. A deteção precoce e controlo das consequências de incidentes biológicos dependem da solidez e flexibilidade do sistema de Saúde Pública nos seus níveis local, distrital, regional e central. 
Os profissionais de saúde devem estar informados e atentos porque, muito provavelmente, serão eles os primeiros a observar, tratar e controlar situações de saúde não habituais.

Os princípios epidemiológicos devem ser usados para avaliar se a apresentação de um paciente é típica de uma doença endémica ou é um acontecimento imprevisto que deve causar preocupação. Existem recursos citados por English et al. (1999) que devem alertar o profissional de saúde para a possibilidade de um surto relacionado com Bioterrorismo:

- Aumento rápido da incidência de uma doença (vai de horas a dias) numa população saudável;

- Uma curva epidémica que sobe ou desce durante um curto período de tempo;

- Um aumento anormal de pessoas que procuram cuidados de saúde, especialmente com febre, queixas respiratórias e gastrointestinais;

- Uma doença endémica que emerge rapidamente num período de tempo atípico com um padrão fora do normal;

- Menor taxa de contágio entre pessoas que estiveram em ambientes fechados, especialmente em áreas com ar filtrado ou sistemas de ventilação fechado em comparação com pessoas que estiveram no exterior;

- $\quad$ grupo de pessoas que surgem todas de um único local ou área;

- Um grande número de casos que evoluem rapidamente para a morte;

- Qualquer pessoa que apresente sintomas de doença relativamente incomum, tem potencial bioterrorista (Ex. $^{\circ}$ carbúnculo pulmonar, tularémia, peste).

Mediante este cenário, surge a necessidade da criação de condições para responder de forma rápida e coordenada, caso ocorra uma ameaça ou ato de Bioterrorismo.

Um plano deverá ser abrangente e flexível o suficiente para abranger uma grande variedade de cenários, contudo é difícil abranger todas as possibilidades. Poderão ser realizados procedimentos detalhados adicionais, protocolos e algoritmos a nível de diferentes departamentos (Shultz et al., 2002).

O Plano em Portugal será organizado de acordo com as orientações publicadas pela CN n¹2/DT de 02-092002 da DGS que define 5 fases. As fases do plano são definidas em função da existência de ameaças/ações de terrorismo biológico:
Fase 0 - Consciência do risco, sem ameaça potencial (Período inter-crise).

Fase 1 - Alerta em função de ameaça potencial/ plausível de ações de Bioterrorismo.

Fase 2 - Alerta em função de aparecimento de situações confirmadas de Bioterrorismo noutro(s) país(es).

Fase 3 - Estado de alerta nacional por ocorrência, em Portugal, de situações suspeitas/confirmadas de Bioterrorismo.

Fase 4 - Período pós-crise de retorno à Fase 0.

Cada fase pressupõe uma variedade de atividades de preparação e resposta de modo a atuar da forma mais adequada ao momento.

Este plano fornece orientações em diversas áreas essenciais para uma resposta completa por parte do hospital, desde a ameaça potencial de um ataque, passando pela fase de casos em outros países e no nosso país, até às medidas de avaliação pós-crise.

As grandes áreas que este plano contempla são a vigilância epidemiológica dos agentes potenciais, planeamento, informação e comunicação, formação e treino, controlo de infeção, saúde ocupacional, uso e administração de vacinas e antivíricos, acesso ao hospital, atendimento aos doentes, capacidade de resposta do hospital, apoio médico-legal, psicossocial e aspetos éticos.

O plano poderá sofrer alterações mediante a evolução da situação.

\section{Conclusão}

A conceptualização estratégica e tática do Bioterrorismo existe já há muitos anos, contudo "A ameaça das armas biológicas é real e está a aumentar, conduzida por descobertas científicas e convulsões políticas no mundo" (Miller et al., 2001).

Da maior importância na luta contra o Bioterrorismo é a deteção rápida de uma libertação de agentes e a transmissão imediata do alerta e de informações relevantes àqueles que têm a seu cargo a preparação da resposta adequada.

Os profissionais de saúde de primeira linha deverão manter um grande índice de suspeita para os agentes de Bioterrorismo, e estarem capazes de fazer um diagnóstico rápido e iniciar tratamento empírico precocemente.

Poder-se-à aquilatar, que Portugal tem feito alguns esforços, embora possam não ser os suficientes, para se preparar para enfrentar uma possível ameaça desta natureza. Assim, no que respeita à prevenção, Portugal assinou e validou quer o Protocolo de 
Genebra quer a Convenção das Armas Biológicas de 1972 e integra as várias organizações internacionais com responsabilidades nesta matéria (Pires e Silva, 2009). Quanto à preparação, Portugal dispõe de um Plano de Contingência para a Saúde em caso de Bioterrorismo e de um Plano de Emergência de Proteção Civil. No que diz respeito à deteção, esta baseia-se tanto na vigilância epidemiológica, atualmente a cargo do Instituto Nacional de Saúde Dr. Ricardo Jorge, como na deteção dos agentes envolvidos, da responsabilidade, principalmente do mesmo Instituto e do Laboratório de Defesa Biológica do Exército. Tratando-se o Bioterrorismo de um crime não se pode esquecer de salientar a importância da PJ na investigação desta situação.

Contudo, considerando o período de recessão que caracteriza o Mundo em geral e Portugal em particular e considerando que a posição do Ministério da Saúde passa pela centralização de especialidades e dos SU, é nossa opinião ser de repensar o atual sistema de socorro e combate ao Bioterrorismo instituído em Portugal. Pensa-se que existirão várias entidades com os mesmos meios, pelo que deverá ser feita uma avaliação dessa distribuição. Após essa avaliação deverá ser realizado um Plano de Emergência a nível nacional que envolva as várias entidades da Proteção Civil.

\section{Apêndice}

\section{NIAID Emerging Infectious Diseases/Pathogens}

Emerging infectious diseases can be defined as infectious diseases that have newly appeared in a population or have existed but are rapidly increasing in incidence or geographic range, or that are caused by one of the NIAID Category A, B, or C priority pathogens.

The NIAID Emerging Infectious Diseases/Pathogens category includes Biodefense Research and Additional Emerging Infectious Diseases/Pathogens.

\section{NIAID Biodefense Research}

\section{NIAID Category A, B, and C Priority Pathogens}

NIAID's pathogen priority list is periodically reviewed and is subject to revision in conjunction with our federal partners, including the U.S. Department of Homeland Security, which determines threat assessments, and the Centers for Disease Control and Prevention, which is responsible for responding to emerging pathogen threats in the United States.

Category A pathogens are those organisms/biological agents that pose the highest risk to national security and public health because they:
- Can be easily disseminated or transmitted from person to person;

- Result in high mortality rates and have the potential for major public health impact;

- Might cause public panic and social disruption;

- Require special action for public health preparedness.

\section{Category A Priority Pathogens}

- $\quad$ Bacillus anthracis (anthrax);

- Clostridium botulinum toxin (botulism);

- Yersinia pestis (plague);

- Variola major (smallpox) and other related pox viruses;

- Francisella tularensis (tularemia);

- Viral hemorrhagic fevers:

- Arenaviruses: Junin, Machupo, Guanarito, Chapare (new in fiscal year (FY) 14), Lassa, Lujo (new in FY 14;

- Bunyaviruses: Hantaviruses causing Hanta Pulmonary syndrome, Rift Valley Fever, Crimean Congo Hemorrhagic Fever;

- Flaviruses:Dengue;

- Filoviruses: Ebola, Marburg

Category B pathogens are the second highest priority organisms/biological agents. They:

- $\quad$ Are moderately easy to disseminate;

- Result in moderate morbidity rates and low mortality rates;

- Require specific enhancements for diagnostic capacity and enhanced disease surveillance.

\section{Category B Priority Pathogens}

- $\quad$ Burkholderia pseudomallei (melioidosis);

- $\quad$ Coxiella burnetii (Q fever);

- $\quad$ Brucella species (brucellosis);

- $\quad$ Burkholderia mallei (glanders);

- $\quad$ Chlamydia psittaci (Psittacosis);

- $\quad$ Ricin toxin (Ricinus communis);

- $\quad$ Epsilon toxin (Clostridium perfringens);

- $\quad$ Staphylococcus enterotoxin B (SEB);

- $\quad$ Typhus fever (Rickettsia prowazekii) 
- $\quad$ Food- and waterborne pathogens

- Bacteria (Diarrheagenic E.coli, Pathogenic Vibrios, Shigella species, Salmonella, Listeria monocytogenes, Campylobacter jejuni, Yersinia enterocolitica);

- $\quad$ Viruses (Caliciviruses, Hepatitis A);

- Protozoa (Cryptosporidium parvum, Cyclospora cayatanensis, Giardia lamblia, Entamoeba histolytica, Toxoplasma gondii, Naegleria fowleri (new in FY 14), Balamuthia mandrillaris (new in FY 14);

- $\quad$ Fungi (Microsporidia);

- Mosquito-borne encephalitis viruses:

- $\quad$ West Nile virus (WNV);

- $\quad$ LaCrosse encephalitis (LACV);

- California encephalitis;

- Venezuelan equine encephalitis (VEE);

- $\quad$ Eastern equine encephalitis (EEE);

- Western equine encephalitis (WEE);

- Japanese encephalitis virus (JE);

- $\quad$ St. Louis encephalitis virus (SLEV).

Category $C$ pathogens are the third highest priority and include emerging pathogens that could be engineered for mass dissemination in the future because of:

- $\quad$ Availability;

- $\quad$ Ease of production and dissemination;

- $\quad$ Potential for high morbidity and mortality rates and major health impact

\section{Category C Priority Pathogens}

- $\quad$ Nipah and Hendra viruses;

- $\quad$ Additional hantaviruses;

- Tickborne hemorrhagic fever viruses:

- Bunyaviruses (Severe Fever with Thrombocytopenia Syndrome virus (SFTSV), Heartland vírus);

- $\quad$ Flaviruses (Omsk Hemorrhagic Fever virus, Alkhurma virus, Kyasanur Forest vírus);

- Tickborne encephalitis complex flaviviruses:

- $\quad$ Tickborne encephalitis viruses;

- $\quad$ European subtype;

- $\quad$ Far Eastern subtype;
- $\quad$ Siberian subtype;

- Powassan/Deer Tick virus.

- Yellow fever virus;

- $\quad$ Tuberculosis, including drug-resistant TB;

- Influenza virus;

- Other Rickettsias:

- Rabies virus;

- Prions;

- Chikungunya virus;

- Coccidioides spp.;

- $\quad$ Severe acute respiratory syndrome associated coronavirus (SARS-CoV), MERS-CoV, and other highly pathogenic human coronaviruses (new in FY 14);

- Antimicrobial resistance, excluding research on sexually transmitted organisms, unless the resistance is newly emerging*:

- Research on mechanisms of antimicrobial resistance;

- $\quad$ Studies of the emergence and/or spread of antimicrobial resistance genes within pathogen populations;

- $\quad$ Studies of the emergence and/or spread of antimicrobial-resistant pathogens in human populations;

- Research on therapeutic approaches that target resistance mechanisms;

- Modification of existing antimicrobials to overcome emergent resistance.

- Antimicrobial research, as related to engineered threats and naturally occurring drug-resistant pathogens, focused on development of broadspectrum antimicrobials

*NIAID Category C Antimicrobial Resistance-Sexually Transmitted Organisms Excluded

- Bacterial vaginosis, Chlamydia trachomatis, cytomegalovirus, Granuloma inguinale, Hemophilus ducreyi, hepatitis $B$ virus, hepatitis $C$ virus, herpes simplex virus, human immunodeficiency virus, human papillomavirus, Treponema pallidum, Trichomonas vaginalis.

\section{Immunological Studies}

Immunology studies that advance our understanding of host defenses applicable to the biodefense effort, for example: 
- $\quad$ Adjuvants;

- Innate Immunity;

- $\quad$ Adaptive Immunity;

- Mucosal Immunity

\section{Additional Emerging Infectious Diseases/Pathogens}

- Acanthamebiasis;

- $\quad$ Anaplasmosis (new in FY 14);

- $\quad$ Aspergillus (new in FY 14);

- $\quad$ Australian bat lyssavirus;

- Babesia, atypical;

- Bartonella henselae;

- $\quad$ BK virus (new in FY 14);

- $\quad$ Bordetella pertussis (new in FY 15);

- $\quad$ Borrelia miyamotoi (new in FY 14);

- $\quad$ Clostridium difficile;

- $\quad$ Cryptococcus gattii (new in FY 14);

- $\quad$ Ehrlichiosis;

- $\quad$ Enterococcus faecium and faecalis (new in FY 14);

- $\quad$ Enterovirus 68 (new in FY 15);

- $\quad$ Enterovirus 71;

- $\quad$ Hepatitis C (new in FY 14);

- $\quad$ Hepatitis E (new in FY 14);

- Human herpesvirus 8;

- Human herpesvirus 6;

- $\quad J C$ virus (new in FY 14);

- $\quad$ Leptospirosis (new in FY 14);

- $\quad$ Lyme borreliosis;

- $\quad$ Mucormycosis (new in FY 14);

- Mumps virus;

- $\quad$ Poliovirus (new in FY 15);

- $\quad$ Rubeola (measles) (new in FY 14);

- $\quad$ Streptococcus, Group A;

- Staphylococcus aureus;

Notes:

* This list was created for the purpose of extramural and intramural program management within the NIAID
biodefense/EID mission and does not represent the complete scope of biodefense and emerging infectious disease.

${ }^{* *}$ HIV/AIDS is excluded.

Last Updated February 25, 2015

\section{Referências Bibliográficas}

Álamo, S. (2004). Ataque NBQ y su impacto psicológico en la población. Perú. http://www.monografias. com/trabajos17/ataque-biologico/ataquebiologico.shtml, acedido em Outubr de 2015.

Alves, A. (2004). Plano de Emergência Hospitalar. In: Marques, A., Sousa, P. (eds) Medicina de Emergência, dos Príncipios à Organização, Vol.I, 90-99, Lisboa

Bandeira, R. (2006). A medicina de catástrofe face às doenças transmissíveis no século XXI (dados pessoais). III Congresso Nacional do Médico Interno. Porto.

Bandeira, R. (2008). Medicina de catástrofe: Da exemplificação histórica à iatroética. $1^{\text {a }}$ Edição, Editora da Universidade do Porto. Porto. p. 317.

Bossi, P., Tegnell, A., Baka, A., Van Loock, F., Hendriks, J., Werner, A., Maidhof, H., Gouvras, G. (2004). Bichat guidelines for the clinical management of anthrax and bioterrorism-related anthrax. Vol 9 Issue 12. Eurosurveillance. Luxemburgo.

CDC. (2003b). Smallpox Response Plan: Guide C, Part 2: Quarantine Guidelines. p. 1-8. www.bt.cdc. gov/agent/smallpox/response-plan/, acedido em Outubro de 2015.

CDC. (2009a). Bioterrorism: overview. http://www. bt.cdc.gov/bioterrorism/overview.asp acedido em Outubro de 2015.

CDC. (2009b). Bioterrorism: Agents/Diseases. http:// www.bt.cdc.gov/agent/agentlist-category. asp, acedido em Outubro de 2015.

CDC. (2009c). Anthrax. http://emergency.cdc.gov/ agent/anthrax/, acedido em Outubro de 2015.

CDC. (2009d)- Botulism. http://emergency.cdc.gov/ agent/botulism/, acedido em Outubro de 2015.

CDC. (2009e). Plage. http://emergency.cdc.gov/agent/ plague/, acedido em Outubro de 2015.

CDC. (2009f). Smallpox. http://emergency.cdc.gov/ agent/smallpox/, acedido em Outubro de 2015.

CDC. (2009g). Tularemia. http://emergency.cdc.gov/ agent/tularemia/, acedido em Outubro de 2015.

CDC. (2009h). FH. http://www.cdc.gov/ncidod/dvrd/ $\mathrm{spb} / \mathrm{mnpages/dispages/vhf.htm,} \mathrm{acedido} \mathrm{em}$ Outubro de 2015.

Cevallos, D. (2001). Bioterrorismo enciende alarmas en América Latina. Tierrámerica médio ambiente y desarrollo. http://www.tierramerica. net/2001/1021/articulo.shtml, acedido em Janeiro de 2010.

DHHS (2008). Guidance on emergency responder personal protective equipment for response to CBRN terrorismo incidentes. Publication $\mathrm{n}^{\circ}$ 2008-132. NIOSH. EUA. 
Cunha, S. (2005). Global Fear Epidemiology: the key consequence of terrorism. (dados pessoais). INEM. Porto.

ECDC. (2009). Annual epidemiological report on communicable diseases in Europe. Surveillance report. Estocolmo. p. 221. http://www.ecdc. europa.eu/en/publications/surveillance reports/Pages/index.aspx, acedido em Março de 2010.

ECDC. (2010). Anthrax outbreak among drug users, Scotland and Germany. http://www. ecdc.europa.eu/en/activities/sciadvice/ Lists/ECDC\%20Reviews/ECDC_DispForm. aspx? List $=512 \mathrm{ff} 74 \mathrm{f}-77 \mathrm{~d} 4-4 \mathrm{ad} 8-\mathrm{b} 6 \mathrm{~d} 6$ bf0f23083f30\&ID=711, acedido em Março de 2010.

ECDC. (2013). Annual epidemiological report: reporting on 2011 surveillence data and 2012 epidemic intelligence data. Estocolmo. p. 135

English, J., Cundiff, M., Malone, J., Pfeiffer, J., Bell, M., Steel, L., Miller, M. (1999). Bioterrorism Readiness Plan: A Template for Healthcare Facilities. APIC e CDC. p.33. www.cdc.gov/ ncidod/.../13apr99APIC-CDCBioterrorism.PDF, acedido em Novembro de 2009.

EUR-Lex. (2010). Comunicação da Comissão ao Conselho e ao Parlamento Europeu sobre a cooperação na união europeia em matéria de prevenção e de capacidade de resposta a ataques com agentes biológicos e químicos (segurança sanitária) /* COM/2003/0320 final. http:// eur-lex.europa.eu/LexUriServ/LexUriServ.do? uri=CELEX:52003DC0320:PT:HTML, acedido em Outubro de 2015.

Ferreira, M. (2006). Plano de Emergência externa do Hospital Pedro Hispano. Porto.

Henretig, F., Cieslak, T., Kortepeter, M., Fleisher, G. (2002). Management of the suspected of bioterrorism: an algorithmic to the undifferentiated patient. Vol.20. Emergency Medicine Clinics of North America. EUA. p. 351-364.

HSJ (2004). Plano de emergência interna e externa. Porto

INSA (2015). Comunicado conjunto sobre botulismo alimentar. Lisboa. http://www.insa.pt/sites/ INSA/Portugues/Comlnf / Noticias/Paginas/ Comunicadoconjuntobotulismo.aspx, acedido em Outubro de 2015

INTERPOL. (2009). About bioterrorism. http://www. interpol.int/Public/BioTerrorism/Definition. asp, acedido em Janeiro de 2010.

Mandell, G., Bennett, J. e Dolin, R. (2005). Principles and practices of infectious diseases. $6^{a}$ Edição. Editora Churchill Livingstone.

Miller, J, Engelbert, S., Broad, W. (2001). Micróbios: As armas biológicas e a guerra secreta da América. Terramar. p. 348.

Montoya, R. (2009). Armas Biológicas. http://www. educacional.com.br/reportagens/armas/ biologicas.asp, acedido em Outubro de 2015.

NATIONAL INSTITUTE FOR OCCUPATIONAL SAFETY AND HEALTH (NIOSH). (2009). Recommendations for the selection and use of respirators and protective clothing for protection against biological agents. $\mathrm{n}^{\circ} 132$.

NIAID (2015) Emerging Infectious Diseases/Pathogens. http: / / www.niaid.nih.gov/topics / biodefenserelated/biodefense/pages/cata. aspx, acedido em Outubro de 2015.
PHTLS (2011). Explosões e armas de destruição em massa. NAEMT, $7^{\mathrm{a}}$ Ed. Mosby/ELSEVIER. p. 447475.

Pires, F., Silva, A. (2009). A utilização da engenharia genética na produção de armas biológicas. http: / / www.revistamilitar.pt/modules/ articles/article.php?id=347, acedido em Fevereiro de 2009.

Sanchez-Yáñez, J., Menjivar, G. (2008). Ataques biológicos contra la sociedad humana, ¿Ficción o realidad?. México. http: //www. monografias. com/trabajos62/ataques-biologicos-sociedadhumana/ataques-biologicos-sociedad-humana. shtml, acedido em Outubro de 2015.

SAÚDE-EU. (2009). Bioterrorismo. http://ec.europa.eu/ health-eu/my_environment/bio_terrorism/ index_pt.htm, acedido em Outubro de 2015.

Schultz, C., Mothershead, J., Field, M. (2002). Bioterrorism preparedness I: the emergency department and hospital. Vol 20. Emergency Medicine Clinics of North America. EUA. p. 409-455

Siegel, J., Rhinehart, E., Jackson, M., Chiarello, L., and the Healthcare Infection Control Practices Advisory Committee (2007 com revisão a 2014) Guidance for isolation precautions: preventing transmission of infectious agentes in healthcare settings. CDC. 2007 com revisão a 2014.

Soler, D., Correr M., Guadarrama L. (2008). Manual de triage prehospitalario. Elsevier Espanha. Barcelona.

Tavolaro, A. (2004). Bioterrorismo e o comércio exterior. Brasil. http://www.tavolaroadvogados.com/ doutrina/cs544.pdf, Acedido em Outubro de 2015.

UNIFEST. (2009). Armas biológicas: histórico. http:// www.virtual.epm.br/material/tis/curr-med/ temas/med3/t1a_2000/ArmasBiologicas/hist frame.htm, acedido em Dezembro de 2009.

WHO. (2009a). Smallpox. http://www.who.int/ mediacentre/factsheets/smallpox/en/index. html, acedido em Novembro de 2009.

WHO. (2009b). Anthrax. http://www.who.int/csr/ disease/Anthrax/en/index.html, acedido em Outubro de 2015.

WHO. (2009c). Botulism. http://www.who.int/ mediacentre/factsheets/fs270/en/, acedido em Outubro de 2015.

WHO. (2009d). Plage. http://www. who.int/csr/disease/ plague/en/index.html, acedido em Outubro de 2015.

WHO. (2009e). Tularemia. http://www. who.int/topics/ tularaemia/en/, acedido em Outubro de 2015.

\section{Legislação}

Lei $n^{\circ}$ 52/2003 de 22 de Agosto. Diário da República n¹93/2003 - I Série - A. Assembleia da República. Lisboa.

Lei $n^{\circ}$ 27/2006 de 03 de Julho. Diário da República n¹26/2006 - I Série. Assembleia da República. Lisboa.

Lei $n^{\circ}$ 53/2007 de 31 de Agosto. Diário da República n¹68/2007 - I Série. Assembleia da República. Lisboa. 
Lei n 37/2008 de 06 de Agosto. Diário da República n 151 / 2008 - I Série. Assembleia da República. Lisboa.

Lei Orgânica $n^{\circ} 1-A / 2009$ de 7 de Julho. Diário da República n²9/2009, I Série. Assembleia da República. Lisboa.

Decreto-lei $n^{\circ}$ 22/2006 de 02 de Fevereiro. Diário da República n²4/2006 - I Série-A. Ministérios da Administração Interna. Lisboa.

Decreto-lei $n^{\circ} 134 / 2006$ de 25 de Julho. Diário da República n¹42/2006 - I Série. Ministério da Administração Interna. Lisboa.

Decreto-lei $n^{\circ} 75 / 2007$ de 29 de Março. Diário da República n63/2007 - I Série. Ministério da Administração Interna. Lisboa.
Decreto-lei $n^{\circ}$ 220/2007 de 29 de Maio. Diário da República n¹03/2007 - I Série. Ministério da Saúde. Lisboa.

Decreto Regulamentar $n^{\circ}$ 66/2007 de 29 de Maio. Diário da República n¹03/2007 - I Série. Ministério da Saúde. Lisboa.

Despacho n¹8923/2002 de 26 de Agosto. Diário da República n¹96/2002 - II Série. Ministério da Saúde, Gabinete do Ministro. Lisboa.

Resolução do Conselho de Ministros n. ${ }^{\circ}$ 87/2013. Diário da República n²40/2013 - I Série.Lisboa.

Circular Normativa n¹2/DT de 02 de Setembro de 2002. DGS. Lisboa 

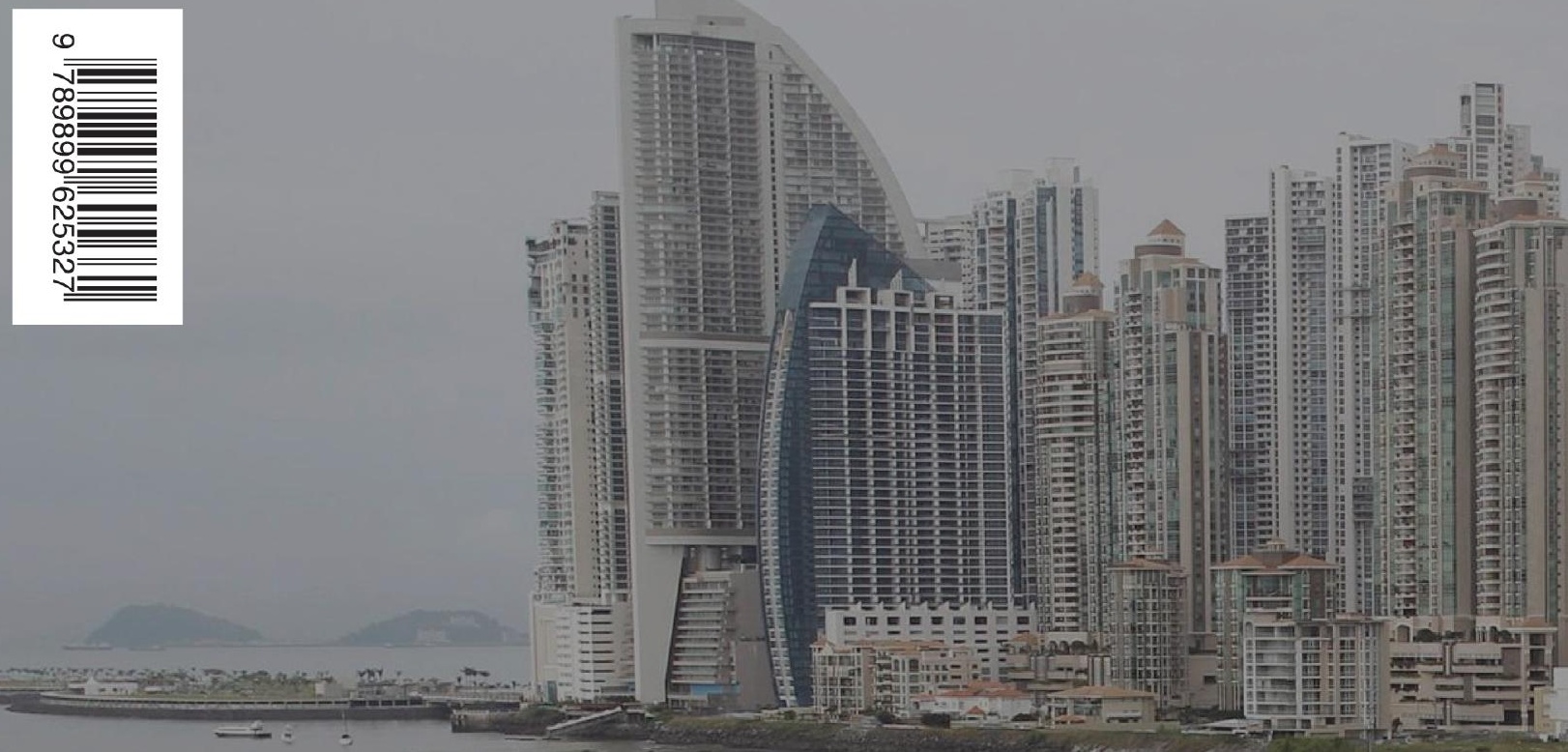

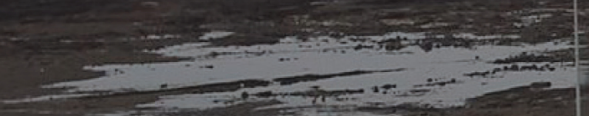

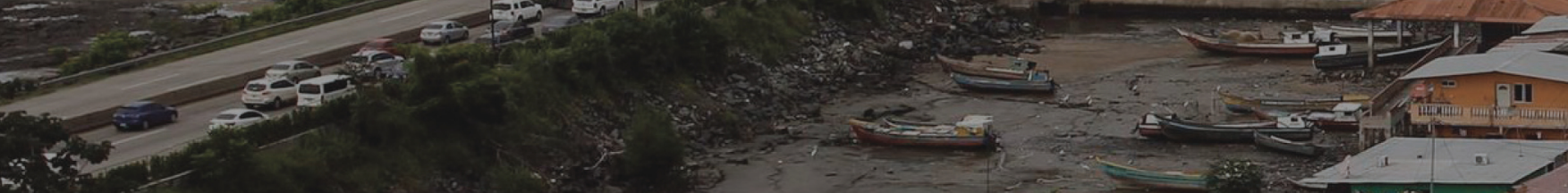

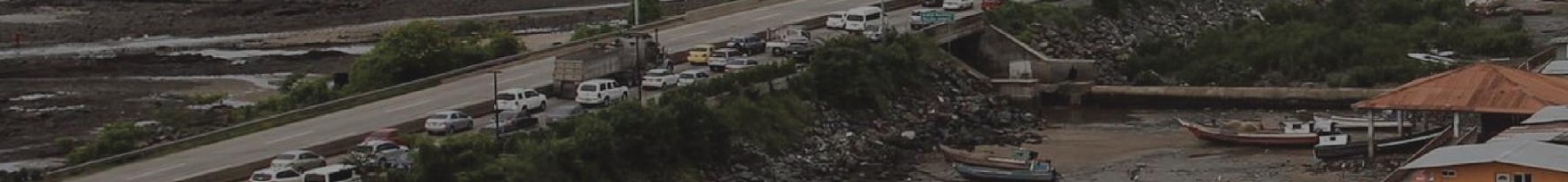
inse- $n=$ Riscos I I I

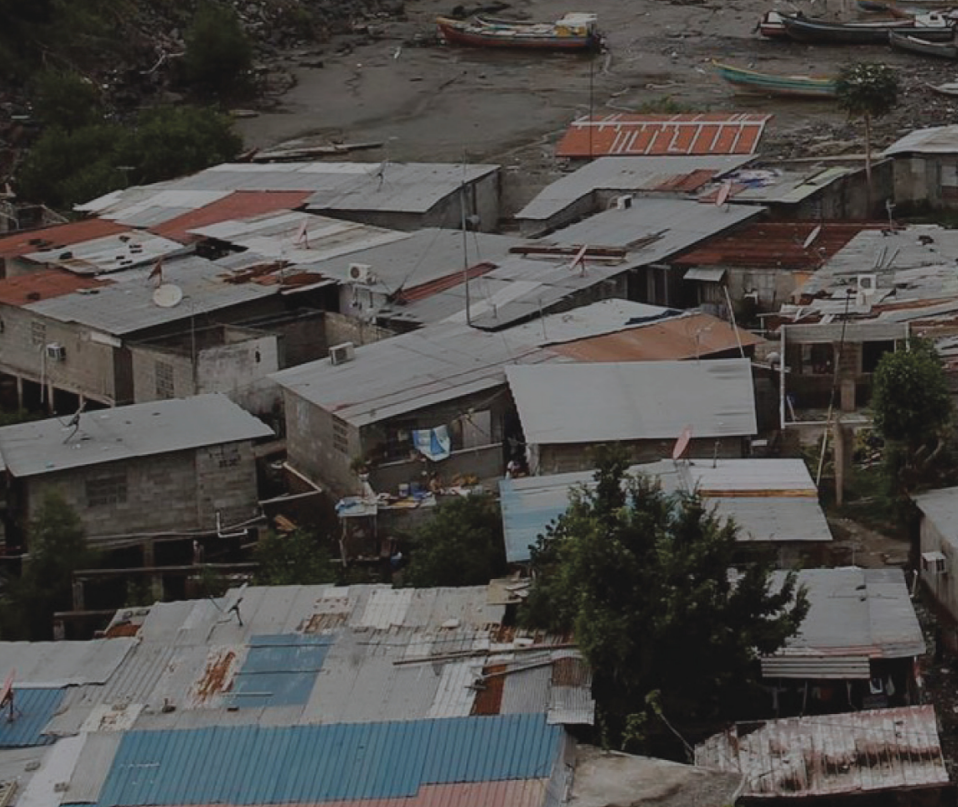

